\title{
Metabolic Profile, Bioactivities, and Variations in the Chemical Constituents of Essential Oils of the Ferula Genus (Apiaceae)
}

\author{
Priyankaraj Sonigra and Mukesh Meena ${ }^{* \dagger}$ \\ Laboratory of Phytopathology and Microbial Biotechnology, Department of Botany, Mohanlal Sukhadia University, Udaipur, India
}

\section{OPEN ACCESS}

Edited by:

Marcello Locatelli,

University of Studies G d'Annunzio

Chieti and Pescara, Italy

Reviewed by: Majid Mohammadhosseini, Islamic Azad University,

Shahrood, Iran

Mohamad Reza Naghavi,

University of Tehran, Iran

*Correspondence:

Mukesh Meena mukeshmeenam/su@gmail.com drmukeshmeena321@mlsu.ac.in

tORCID:

Mukesh Meena orcid.org/0000-0002-6336-1140

Specialty section:

This article was submitted to Ethnopharmacology, a section of the journal Frontiers in Pharmacology

Received: 17 October 2020 Accepted: 11 December 2020 Published: 12 March 2021

Citation:

Sonigra $P$ and Meena M (2021) Metabolic Profile, Bioactivities, and Variations in the Chemical Constituents of Essential Oils of the Ferula Genus

(Apiaceae).

Front. Pharmacol. 11:608649. doi: 10.3389/fphar.2020.608649
The genus Ferula is the third largest and a well-known genus of the Apiaceae family. It is categorized in the Peucedaneae tribe and Ferulinae subtribe of the Apiaceae family. At present, about 180 Ferula species have been reported. The genus is mainly distributed throughout central and South-West Asia (especially Iran and Afghanistan), the far-East, North India, and the Mediterranean. The genus Ferula is characterized by the presence of oleo-gum-resins (asafoetida, sagapenum, galbanum, and ammoniacum) and their use in natural and conventional pharmaceuticals. The main phytochemicals present in the genus Ferula are as follows: coumarin, coumarin esters, sesquiterpenes, sesquiterpene lactones, monoterpene, monoterpene coumarins, prenylated coumarins, sulfur-containing compounds, phytoestrogen, flavonoids and carbohydrates. This genus is considered to be a valuable group of medicinal plants due to its many different biological and pharmacological uses as volatile oils (essential oils). Numerous biological activities are shown by the chemical components of the essential oils obtained from different Ferula species. Because this genus includes many bioactivities such as antimicrobial, insecticidal, antioxidant, cytotoxic, etc., researchers are now focusing on this genus. Several reviews are already available on this particular genus, including information about the importance and the uses of all the phytochemicals found in the species of Ferula. Despite this, no review that specifically provides information about the biological activities of Ferula-derived essential oils, has been published yet. Therefore, the present review has been conducted to provide important information about the chemical profile, factors affecting the chemical composition, and biological activities of essential oils of the Ferula species.

Keywords: antimicrobial, antioxidant, cytotoxic, essential oils, Ferula species, phytochemicals

\section{INTRODUCTION}

Medicinal plants are considered to be an invaluable and a constant source of biologically active phytochemicals. Amid all the other medicinal plants, spices are an important element of Ayurveda. Instead of being an irreplaceable part of food accessories, they have their history in the field of folk medicine since they possess different phytochemicals (Amalraj and Gopi, 2017). These phytochemicals have long been used to cure several ailments, and they can be a promising alternative to conventional medical therapies (Upadhyay, 2017). The Apiaceae family consists of about 455 genera and 3,600-3,751 plants species that belong to this family are often used in the form 
of spices. Ferula is the 3rd largest genus of the Apiaceae family and is categorized in the Peucedaneae tribe and Ferulinae subtribe of the family. At present, about 180 Ferula species have been reported. Ferula is a Latin word meaning "vehicle" or "carrier" (Iranshahy and Iranshahi, 2011). The genus has a wide distribution all over central and South-West Asia (especially Iran and Afghanistan), the far-East, North India, and the Mediterranean (Hosseinzadeh et al., 2020a; Hosseinzadeh et al., 2020b), and some are distributed in desert areas. Most of the Ferula species grow in mountainous regions and arid climates (Yaqoob and Nawchoo, 2016). The Ferula species has been of great importance in folk and traditional medicine for more than a 1,000 years. The genus Ferula is characterized by the presence of oleo-gum-resins (asafoetida, sagapenum, galbanum, and ammoniacum) (Ahmadi et al., 2020).

The main chemical constituents present in the genus Ferula are as follows: coumarin (ferulenol, galbanic acid and umbelliprenin), coumarin esters (ferulone A, B), sesquiterpenes (germacranes, himachalanes, carotanes, humulanes, guaianes, daucane esters farnesiferol $\mathrm{A}$ and $\mathrm{B}$, and sinkiangenorin $\mathrm{C}$ and $\mathrm{E}$ ) (Zellagui et al., 2012), sesquiterpene lactones, monoterpene ( $\alpha$-pinene, $\beta$-pinene), monoterpene coumarins (auraptene), prenylated coumarins (ferprenin), sulfur-containing derivatives, phytoestrogen (ferutinin), flavonoids, carbohydrates (galactose, glucuronic acid, arabinose, rhamnose) (Iranshahi et al., 2018; Mohammadhosseini et al., 2019a; Salehi et al., 2019). Generally, aromatic acid lactones sesquiterpenes, coumarins, and sesquiterpene coumarins are present in the roots of Ferula species (Teng et al., 2013), whereas monoterpenes, oxygenated monoterpenoids sesquiterpenes and oxygenated sesquiterpenoid are the main chemical constituents of essential oil present in the aerial parts of Ferula (Mohammadhosseini et al., 2015). Due to the widespread therapeutic effects of this genus, it is being used in folk medicine to treat a variety of diseases and disorders, including skin infections, psychiatric disorders (especially seizure), hyperlipidemia, diabetes, arteries sclerosis, digestive disorders (dysentery), osteoporosis, arthritis, HIV, influenza type A, cancers (uterine cancer), muscle relaxant, rheumatism, headaches, hypertension, toothache and dizziness (Zhou et al., 2017; Meena et al., 2018; Arjmand and Dastan, 2020; Esmaeili et al., 2020).

In the last few decades, research on the phytochemicals of the Ferula species have gained momentum due to their natural origin, effectiveness and low to no unpleasant side effects. In recent years, several biological activities of phytochemicals, isolated from various Ferula species found in different geographical regions, have been reported, such as antimicrobial (Utegenova et al., 2018; Kahraman et al., 2019), insecticidal (Liu et al., 2020; Pavela et al., 2020), aphicidal (Stepanycheva et al., 2012), antihelmintic (Tavassoli et al., 2018), antiprotozoal activity (Bashir et al., 2014; Amin et al., 2016), antimycobacterial (Fallah et al., 2015), antiviral (Zhai et al., 2012; Ghannadi et al., 2014), antioxidant (Deveci et al., 2018; Rahali et al., 2019), anticancer (Asemani et al., 2018; Hosseinzadeh et al., 2020a; Hosseinzadeh et al., 2020b), antitumor (Alizadeh et al., 2018), cytotoxic (Iranshahy et al., 2019; Mahaki et al., 2019), antiproliferative (Verma et al., 2019), acetylcholinesterase inhibitory (Deveci et al., 2018; Karakaya et al., 2019a), antidepressant (Mohammadhosseini, 2016), antiulcer
(Bagheri et al., 2018), muscarinic receptors inhibitory (Khazdair et al., 2015; Gholamnezhad et al., 2018), antihypertensive (Safaeian et al., 2015), anti-epileptic (Kiasalari et al., 2013), antispasmodic (Pavlović et al., 2012), antinociceptive (Bagheri et al., 2014a), phytotoxic (Dastan et al., 2014), hypnotic (Abbasnia and Aeinfar, 2016), antihemolytic and antioxidant (Nabavi et al., 2011), anticoagulant (Han et al., 2010), anticonvulsant (Bagheri at al., 2010; Bagheri et al., 2014a; Bagheri et al., 2014b; Bagheri et al., 2014c) relaxant (Bayrami et al., 2013; Bagheri et al., 2014a; Bagheri et al., 2014b; Bagheri et al., 2014c), memory enhancement (Upadhyay, 2017), increasing digestive enzyme activity (Safari et al., 2019), antigenotoxic (Ozkan et al., 2014; Rezaee et al., 2014), antihyperlipidemic (Yusufoglu et al., 2015; Latifi et al., 2019), antihyperglycemic (Iranshahi and Alizadeh, 2012; Yusufoglu et al., 2015), antidiabetic (Yarizade et al., 2017; Latifi et al., 2019), anxiolytics (Upadhyay et al., 2014; Batra et al., 2020) and antihepatotoxicity (Fatima et al., 2017; Deniz et al., 2019). In these activities, essential oils also make up a minimal but significant share.

Essential oils are defined as volatile aromatic compounds that provide a distinctive flavor, aroma, or scent to a plant (Raut and Karuppayil, 2014; Meena et al., 2017a; Chandran et al., 2020a, Chandran et al., 2020b). They are hydrophobic, lipid-soluble liquid comprised of volatile and non-volatile fractions (Hussain et al., 2008). The volatile fraction includes mono and sesquiterpene components, their oxygenated derivatives, alcohols, aliphatic aldehydes, and esters. On the other hand, non-volatile residues contain carotenoids, flavonoids, fatty acids, and waxes (Aziz et al., 2018). Essential oils are the byproducts of plants' secondary metabolic processes. Essential oils can be synthesized by any of the plant organs such as leaves, buds, flowers stems, fruits, seeds, wood or bark and roots, and are stored in epidermis cells, secretory cells, glandular hairs and plant-cell wall in the form of small droplets (Prakash et al., 2015; Barupal et al., 2019; Mohammadhosseini et al., 2019b; Chandran et al., 2020a). Generally, Ferula species found in warm to temperate climates such as tropical and Mediterranean countries possess essential oils. Ferula deputize an important part of the conventional pharmacopeia of those countries (Bakkali et al., 2008; Meena and Samal, 2019). In this review, we intend to cover different biological activities and clinical applications of essential oils of the Ferula genus described in recent years. Although, many reviews are available on the medicinal and bioactivity of the Ferula species, no review which specifically provides detailed and encompassing information about the biological activities and pharmaceutical applications of various essential oils has been published yet.

\section{PHYTOCHEMISTRY OF ESSENTIAL OILS AND FACTORS AFFECTING THE CHEMICAL CONSTITUENTS OF THE ESSENTIAL OILS}

Essential oils can be considered as liquids that are lighter than water and represent remarkable hydrophobic characteristics involving a 
vast number of valuable natural compounds (Mohammadhosseini et al., 2019b). These secondary metabolites can be extracted from different parts of the plant materials using a variety of classical and advanced methods (Mohammadhosseini, 2017). Approximately 160 chemical compounds have been identified in the essential oils of the Ferula species; these chemical compounds are responsible for all biological activities represented by the essential oils and make them a better choice for industrial purposes (Figure 1). These chemical groups are monoterpene hydrocarbons: limonene, myrcene, $\gamma$-terpinene, $p$-cymene, $\delta$-3-carene, $\alpha$-pinene, and $\beta$-pinene (Znati et al., 2012; Ben et al., 2016; Khalifaev et al., 2018; Malekzadeh et al., 2018; Asilbekova et al., 2019; Karakaya et al., 2019b; Meena and Swapnil, 2019; Tabari et al., 2019, Topdas et al., 2020); oxygenated monoterpenoids: $\alpha$-terpinyl acetate, linalool, sabinene, $\alpha$-terpineol, verbenone, neryl acetate and arcurcumene (Znati et al., 2012; Radulović et al., 2013; Essid et al., 2015; Khoury et al., 2018), sesquiterpene hydrocarbons: germacrene $\mathrm{B}$ and $\mathrm{D}, \beta$-caryophyllene (E)-caryophyllene, bicyclogermacrene, $\alpha$ gurjunene, $\gamma$-elemene, $\gamma$-cadinene and $\delta$-cadinene (Zellagui et al., 2012; Essid et al., 2015; Meena et al., 2017b; Topdas et al., 2020; Ahmadi et al., 2020); oxygenated sesquiterpenoids: $\alpha$-cadinol, caryophyllene oxide, guaiol, $\alpha$-eudesmol (Z)-ocimenone (E)nerolidol (E)-ocimenone, viridiflorol, carotol, epi- $\alpha$-muurolol, hinesol, valerianol and spathulenol (Benchabane et al., 2012; Kasaian et al., 2016; Deveci et al., 2018; Akhzari and Saadatfar, 2019; Baccari et al., 2020; Meena et al., 2020a, Meena et al., 2020b) and sulfur-containing metabolites: dimethyl-trisulphide (E)-1propenylsec-butyl disulfide, sec-butyl-(Z)-propenyl-disulphide, disec-butyl-disulphide,phenol 2-methyl-5-(1-methylethyl), sec-butyl(E)-propenyl-disulphide, 2,5-diethylthiophene, trimethylthiophene and 1-methylpropyl-(1E)-prop-1-en-1-yl-disulfide,bis-[(1methylthio) propyl]-disulfide and 1-methylpropyl-(Z)-prop-1-en1-yl-disulfide (Kavoosi et al., 2013; Kasaian et al., 2016; Oüzek et al., 2017; Hassanabadi et al., 2019) (Table 1). The chemical profile of the essential oil (aerial parts) of Ferula orientalis L. was evaluated by Karakaya et al., (2019a). Pinene ( $\alpha: 75.9 \%$ and $\beta: 3.4 \%)$ was reported as an abundant constituent of the essential oil. Azarnivand et al., (2011) reported the variation in the chemical profile and yield of the essential oil extracted from the dry and fresh aerial parts of Ferula ovina (Boiss.) Boiss. In accordance with the research results, the amount of oil in the fresh aerial parts was higher than the dried aerial plant parts; the percentage of essential oil in the dry and fresh part of F. ovina was observed as $0.4 \%$ and $0.25 \%$, respectively. The chemical profile of the essential oil in fresh (limonene, $\alpha$-pinene, $\beta$-myrcene, cis- $\beta$-ocimene, isosylvestrene, $\beta$-pinene) and dried aerial parts ( $\alpha$-pinene, spathulenol, germacrene $\mathrm{D}, \quad \beta$-caryophyllene, $\alpha$-terpineol and caryophyllene oxide) of $F$. ovina were also varied. In a report, it was observed that when $F$. ovina is consumed in its fresh form, it is poisonous while it is safe in dry form. The reason behind this was the presence of a high percentage of $\beta$-myrcene and limonene in new parts (Azarnivand et al., 2011). The environmental condition, soil texture, altitude, temperature, and precipitation rate also affect the oil content in Ferula species (Figure 2). Moghaddam and Farhadi (2015) revealed the correlation between mean annual temperatures and altitude; moreover, the effect of altitude on the yield and composition of essential oil was also studied. The maximum accumulations of essential oil and the presence of a higher number of sulfur compounds in essential oil were found in Ferula assa-foetida L. The study of chemical profiles of nine samples revealed that (E)-propenyl sec-butyl disulfide (37-54\%) was the abundant compound with (Z)-propenyl secbutyl disulfide (12-23\%) in the essential oils (Hassanabadi et al., 2019). A study showed that decreasing temperature and increasing altitude had a negative correlation with the content of essential oils. In a cluster analysis, it was also concluded that genetic factors have had a greater effect on the chemical constituents of essential oil of $F$. assa-foetida L. compared to the environmental factor. The quality, quantity, and chemical profile of essential oils also differed in accordance with the methods of extraction (Mohammadhosseini and Nekoei, 2014; Kasaian et al., 2016).

The most commonly used essential oil extraction methods are steam distillation and hydro-distillation which are archaic methods that have been around for a long time (Mohammadhosseini, 2016). However, since the late twentieth century, microwave methods, such as solvent-free microwave extraction along with microwave-assisted hydrodistillation have been used for a faster and more effective extraction of plant essential oils (Mohammadhosseini and Nekoei, 2014; Meena et al., 2016; Meena et al., 2017c; Mohammadhosseini et al., 2017; Ragab et al., 2019). Akhzari and Saadatfar (2019) demonstrated the effect of stress conditions on the phytochemistry of essential oil of Ferula haussknechtii $\mathrm{H}$. Wolff ex Rech. f. The result showed that the addition of lead nitrate $(2 \mathrm{mM})$ decreased the myrcene, $\alpha$-, and $\beta$-pinene concentration in the essential oil. The relation between the time of material collection (months) and the chemical composition of essential oil obtained from the oleo-gum-resin of F. assa-foetida, was evaluated by Kavoosi and Rowshan (2013). The oleo-gum-resins (OGRs) collected in three different collection times namely OGR1, OGR2, and OGR3 showed different essential oil chemical compositions (E)-1-propenyl sec-butyl disulfide (23.9\%) and 10-epi-c-eudesmol (15.1\%) were the major constituents in OGR1; whereas (Z)-1-propenyl sec-butyl disulfide and (E)-1-propenyl sec-butyl disulfide with a $27.7 \%$ and $20.3 \%$ quantity in OGR3; $\beta$-pinene $(47.1 \%)$ and $\alpha$-pinene $(21.3 \%)$ were the major constituents in OGR2, respectively. Moreover, Karimian et al., (2020) observed a relationship between the collection time and the essential oil composition and quantity. The OGRs collected in July, August, September, and October showed 9.1\%, 8.2\%, 7.8\%, and $7.4 \%$ oil content, respectively. The chemical compositions of the essential oil also varied in different age groups of plants. The essential oil of the young Ferula assa-foetida H. Karst. plant showed a higher amount of sulfur-containing and sesquiterpene compounds, whereas the essential oil of older plants displayed monoterpene (camphene) as the main chemical group of the essential oil profile (Mohammadi et al., 2019). Khalifaev et al., (2018) revealed the chemical profile of the Ferula kuhistanica Korovin essential oil using plants from two different locations of the central part of Tajikistan. The gas chromatography-flame ionization detector and gas chromatography-tandem mass spectrometry analysis of the hydrodistilled root oil, showed that monoterpene hydrocarbons (86.7\%) had a greater proportion in oil; $a$-pinene $(57.7-70.6 \%)$ was an abundant 


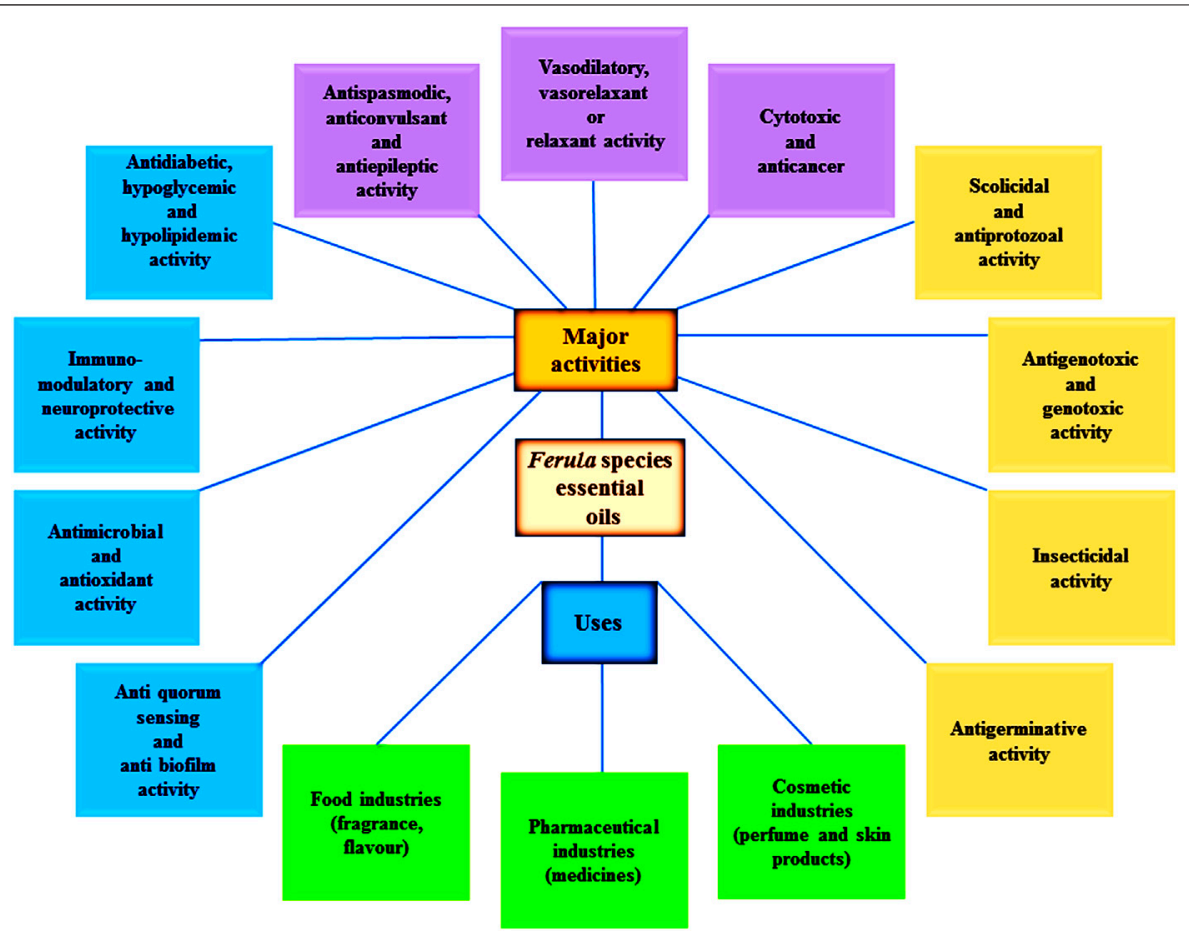

FIGURE 1 | Different bioactivities and uses of the Ferula species essential oils.

monoterpene hydrocarbon, and others include $\beta$-pinene, $\beta$ phellandrene and myrcene. Sagyndykova et al., (2019) identified 47 chemical components in the Ferula foetida (Bunge) Regel essential oil, using the GC-MS analysis. The samples were taken from two different populations (Tuyesu sands and Tynymbay Shoky hills) of the Mangyshlak peninsula which grew in two different types of soil (loamy and sandy). Both of the aforementioned populations were found to have respectable types of chemical components which were as follows; 2,5-dimethyl-2,5-dimethyl-thiophene, 3,4-dimethylthiophene, guaiol, myristicine, bulnesol, $\alpha$-pinene, caryophyllene oxide, 2,5-dipropylthiophene, elemicine, 1heptatriacontanol, $\beta$-trans-caryophyllene, $\beta$-cis-caryophyllene, $\alpha$-caryophyllene, $\beta$-pinene, dimethyl trisulfide, $\alpha$-eudesmol, $\beta$-eudesmol, $\beta$-eudesmene and 2-ethylthieno [3.2-b]thiophene, 5,5-dimethyl-4-[(1E)-3-methyl-1,3-butadienyl]-1-oxaspiro [2.5] octane, S-9-thiabicyclo [3.3.1]non-6-en-2-yl. Asilbekova et al., (2019) assessed the chemical constituents of Ferula kuhistanica's essential oil with their enantiomeric excesses. The results of enantioselective and gas chromatography-tandem mass spectrometry analysis of the essential oil showed compounds with enantiomeric excesses as follows: (+/-)- $\alpha$-pinene (61.9/ 38.1), (+/-)- $\beta$-pinene (28.6/71.4), (+/-)-sabinene (13.2/86.8), and $(+/-)$-limonene $(82.7 / 17.3)$. The results of the study on the essential oils of Ferula aucheri Boiss. Piwczynski, Spalik, M. Panahi \& Puchalka revealed the abundance of sesquiterpene hydrocarbons. The main components of flowering tops oil were germacrene $\mathrm{B}$ and $\beta$-caryophyllene
(14.96 and $12.87 \%$, respectively) and neophytadiene (diterpene compound, $0.18 \%$ ), whereas cis-dihydroagarofuran and $\delta$-cadinene (9.02 and $8.28 \%$, respectively); $\delta$-cadinene and gurjunene were found in fruit and root oils (18.25 and 12.62\%, respectively) (Ahmadi et al., 2020). In a study, Kasaian et al., (2016) reported an abundance of oxygenated sesquiterpenes (74.7\%) and S-containing hydrocarbons (16.6\%) in the hydrodistilled essential oil of Ferula alliacea Boiss. The major components were 10-epi- $\gamma$-eudesmol, valerianol, hinesol, guaiol, and Z-propenyl-sec-butyl trisulphide with $22.3,12.5,8.3$, 7.3, and 6.5\% quantities, respectively. Malekzadeh et al., (2018) assessed the difference in yield and chemical components of the Ferula gummosa Boiss. Essential oils were growing in different types of bioclimates. The galbanum dry weight vs. essential oil amount was found to be the highest in the plants collected from Ebrahim Abad (16.9\%) and the lowest in the plants collected from angouran (11\%). F. gummosa oil contained a higher number of monoterpenes hydrocarbons such as $17-56.55 \%$ of $\alpha$-pinene, $10.44-37.04 \%$ of $\beta$-pinene, $9.16-10.75 \%$ of $\delta$-3-carene, and $0-13.23 \%$ of Limonene, moreover, a chemo-variation was observed in the oils. Kouyakhi et al., (2008) described that the plant samples (Ferula gummosa) collected from the tropical zone had a greater number and better type of flavoring combinations of essential oils as compared to the samples collected from the cold region. The samples collected from the same region, but at different altitudes could affect the chemical profile of a plant's essential oil and reflects the efficacy of environmental effects. Moreover, the samples collected from the different regions and at 
TABLE 1 | Chemical structures of some monoterpene hydrocarbons, oxygenated monoterpenoids, sesquiterpenes hydrocarbons, oxygenated sesquiterpenoids, sulfur containing compounds present in the essential of Ferula genus.<smiles>CC1=CCC2CC1C2(C)C</smiles>

$\alpha$-Pinene<smiles>C=C1CCC2(C(C)C)CC12</smiles>

Sabinene

\section{Monoterpene hydrocarbons}<smiles>C=CC(C)(O)CCC=C(C)C</smiles>

Linalool<smiles>C=CC(=C)CCC=C(C)C</smiles><smiles>C=C(C)C1CC=C(C)CC1</smiles>

Limonene<smiles>CC1=CCC(C(C)(C)O)CC1</smiles>

$\alpha$-Terpineol<smiles>Cc1ccc(C(C)C)cc1</smiles>

p-Cymene<smiles>CC1=CCC2C(C1)C2(C)C</smiles>

8-3-Carene<smiles>CC1=CCC(C(C)C)=CC1</smiles>

$\delta$-Terpinene

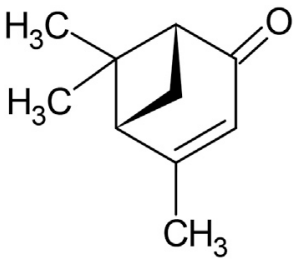

Verbenone (Continued on following page) 
TABLE 1 | (Continued) Chemical structures of some monoterpene hydrocarbons, oxygenated monoterpenoids, sesquiterpenes hydrocarbons, oxygenated sesquiterpenoids, sulfur containing compounds present in the essential of Ferula genus.<smiles>CC(=O)OCC=C(C)CCC=C(C)C</smiles>

Neryl acetate

Oxygenated monoterpenoids

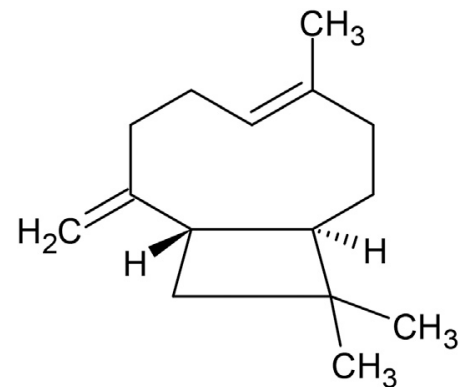

$\beta$-Caryophyllene<smiles>CC1=C[C@H]2C(=C(C)CC[C@@H]2C(C)C)CC1</smiles>

$\delta$-Cadinene

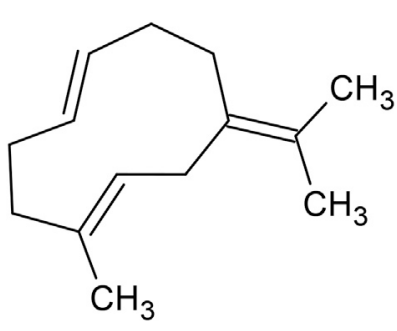

Germacrene B<smiles>C=C1/C=C\C(C(C)C)CC/C(C)=C\CC1</smiles>

Germacrene D

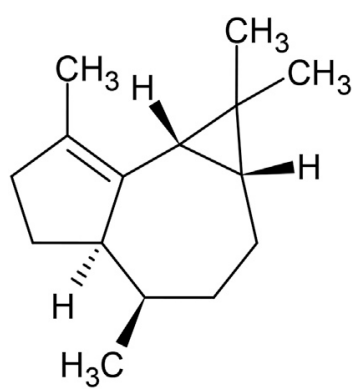

$\alpha$-Gurjunene<smiles>C=C1CC[C@H](C(C)C)[C@H]2C=C(C)CCC12</smiles>

$\gamma$-Cadinene

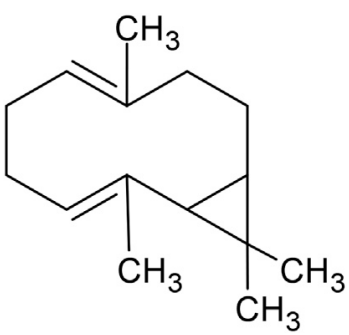

Bicyclogermacrene<smiles>C=CC1(C)CCC(=C(C)C)CC1C(=C)C</smiles>

$\gamma$-Elemene 
<smiles>CC(C)=CCC[C@H](C)c1ccc(C)cc1</smiles>

(s)-Ar-curcumene

\section{Sesquiterpene hydrocarbons}

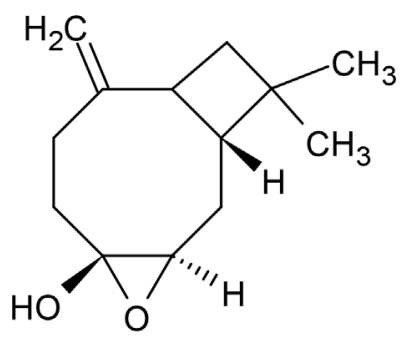

Caryophyllene oxide

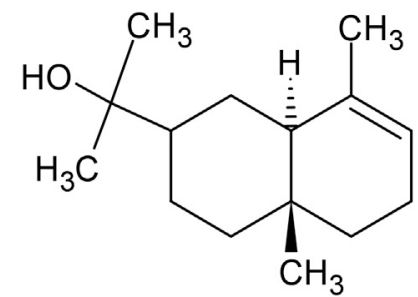

$\alpha$-Eudesmo

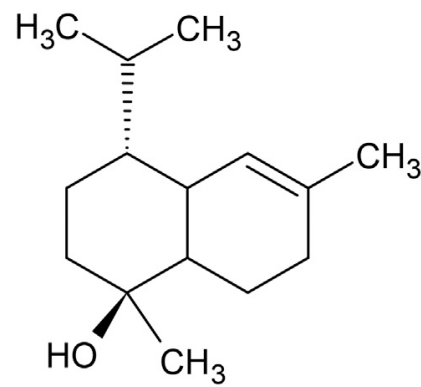

a-Cadinol

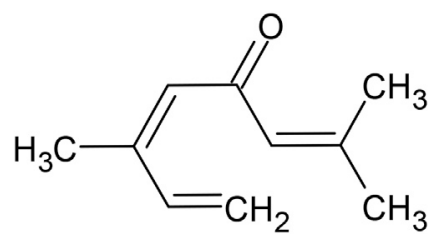

(Z)-Ocimenone

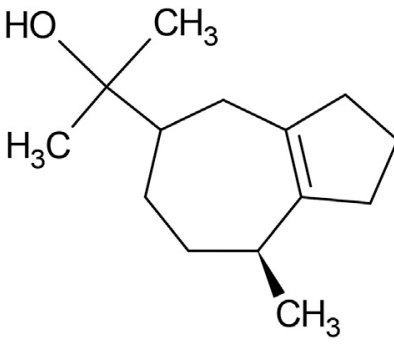

Guaiol<smiles>C=CC=CC(=O)C=C(C)C</smiles>

(E)-Ocimenone 
TABLE 1 | (Continued) Chemical structures of some monoterpene hydrocarbons, oxygenated monoterpenoids, sesquiterpenes hydrocarbons, oxygenated sesquiterpenoids, sulfur containing compounds present in the essential of Ferula genus.

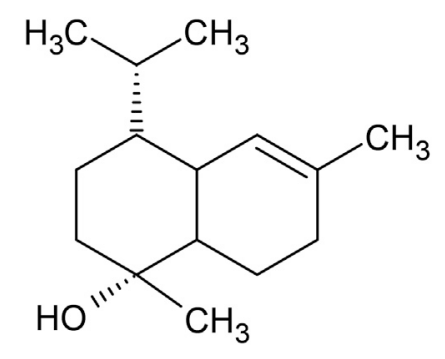

Epi-a-muurolol

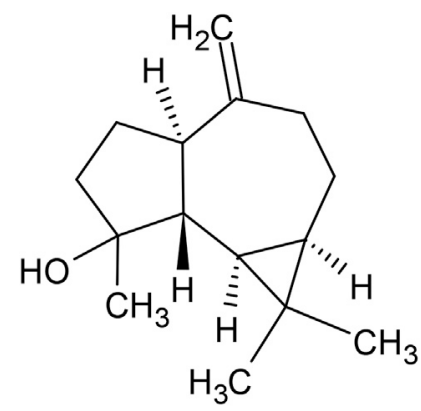

Spathulenol

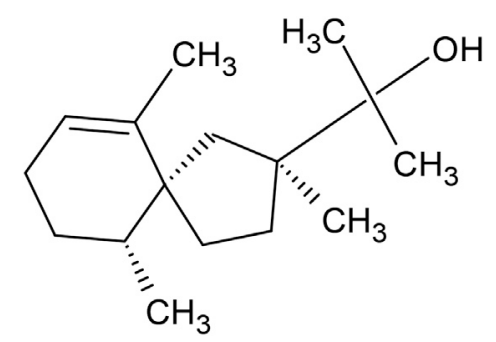

Hinesol

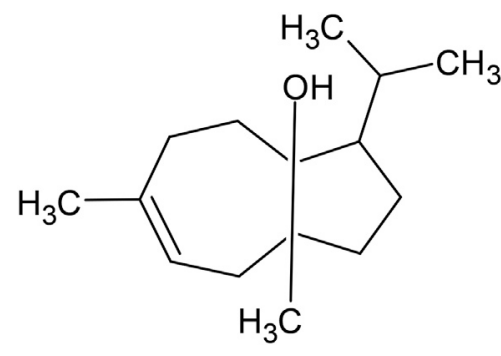

Carotol

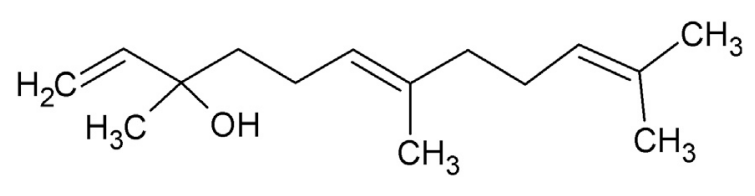

(E)-Nerolidol

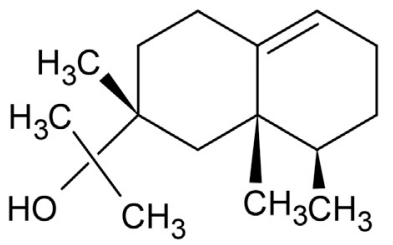

Valerianol

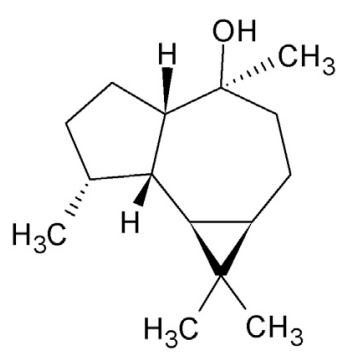

Viridiflorol 
TABLE 1 | (Continued) Chemical structures of some monoterpene hydrocarbons, oxygenated monoterpenoids, sesquiterpenes hydrocarbons, oxygenated sesquiterpenoids, sulfur containing compounds present in the essential of Ferula genus.

\section{Oxygenated sesquiterpenoids}<smiles>CC=CSSC(C)CC</smiles>

(E)-1-Propenyl-sec-butyl disulfide<smiles>Cc1ccc(C)s1</smiles>

2,5-Diethylthiophene<smiles>CC1=CCC(C)=C1C</smiles>

Trimethylthiophene Sulfur-containing compounds<smiles>CSSSC</smiles>

Dimethyl-trisulfide<smiles>CCC(C)SSC(C)C</smiles>

Di-sec-butyl-disulfide<smiles>CC=CSSC(C)CC</smiles>

(Z)-1-Propenyl sec-butyl disulfide<smiles>CCC(SC)SSC(CC)SC</smiles>

Bis-[(1-methylthio) propyl]-disulfide 


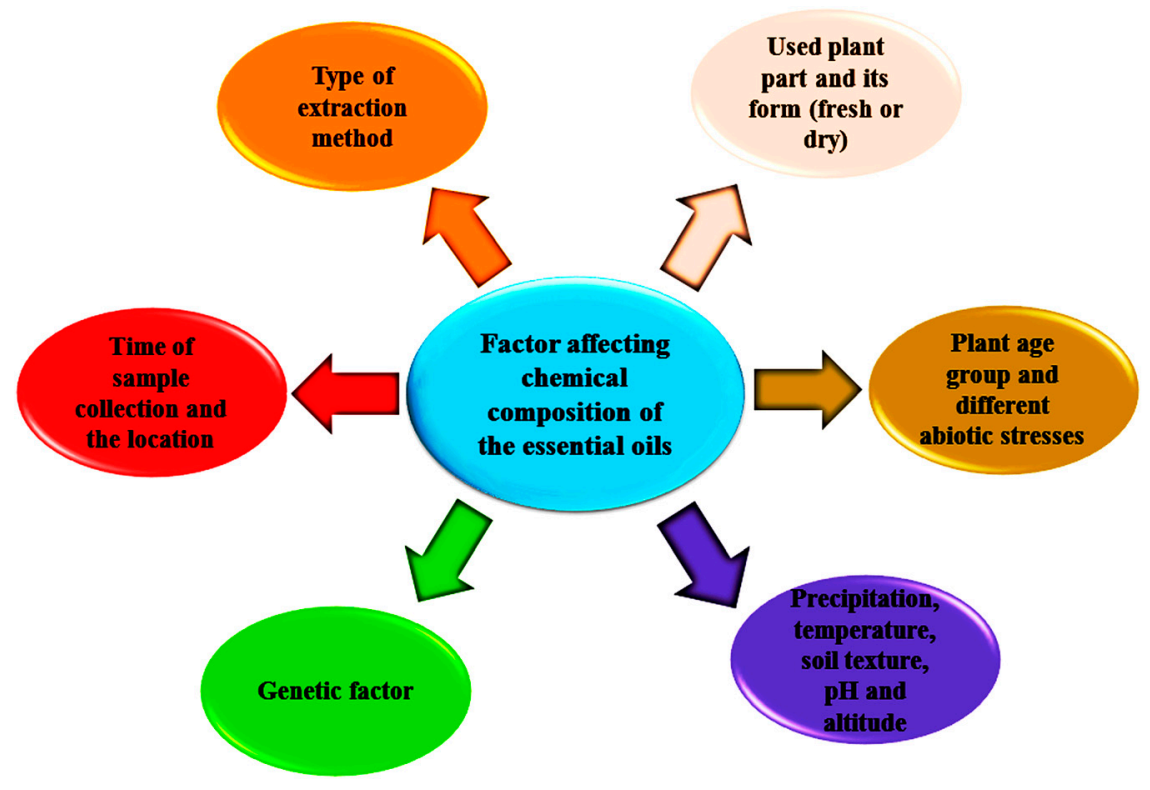

FIGURE 2 | Factors affecting the chemical profile of essential oils of Ferula species.

the same altitude also showed variation in phytochemicals. Using an environmental metabolomics approach, the effect of edaphic factors $(\mathrm{pH}$, texture, and iron, aluminum, and potassium content) and environmental factors (temperature latitude, altitude and longitude) were determined using the essential oils from the roots of 10 Iranian F. assa-foetida. Three different types of plant chemotypes were characterized with different major chemical compounds in their essential oils. A chemotype (I) possessed Z-1-propenyl sec-butyl disulfide and monoterpenes; $\alpha$-agarofuran and eudesmane sesquiterpenoids by chemotype (II); and Z-1-propenyl sec-butyl and E-1propenyl sec-butyl by chemotype (III) Karimi et al., (2020). Fourteen Iranian and Afghan F. assa-foetida L. were investigated for their essential oil composition hydrodistilled from oleo gum-resin using a Clevenger type apparatus; a range of variations among 42 compounds was reported. The major constituent was (E)-1-propenyl sec-butyl disulfide (13.66-49.35\%), $\beta$-pinene (Z)-1-propenyl sec-butyl disulfide, $\alpha$-pinene, thiophene, and thiourea. The results of the analysis showed that the increase in altitude caused an increase in $\beta$-pinene and (Z)-1-propenyl sec-butyl disulfide content, but a reduction in the thiourea content in essential oils. This study showed that altitude was the environmental factor exerting the greatest effect and which caused a great number of variations in the essential oils' chemical components and yield (Hassanabadi et al., 2019). Ferula has many uses in ethnobotany due to its vast phytochemistry but the use of its essential oil has not been seen so much in folk and traditional medicine. Nevertheless, the volatile oils present in the gum of Ferula assa-foetida are released from the body through the lungs, thus, its essential oil is an excellent treatment for asthma. Apart from this, it is also very useful in discharge, breathing, flatus, and gastric erosions (Mahendra and Bisht, 2012).

\section{BIOACTIVITIES OF THE ESSENTIAL OILS FROM THE FERULA SPECIES}

The essential oil extracted from the Ferula species display different types of biological activities. These activities are related to the chemical group present in the essential oils. These bioactivities could be connected to a single compound or group of chemical compounds found in the essential oil. Allimportant biological activities and major chemical constituents of the essential oils from different species of the Ferula genus are shown in Table 2. These bioactivities of essential oils are discussed below.

\section{INSECTICIDAL ACTIVITY}

According to the obtained results, it was concluded that terpenes had active insecticidal properties, particularly as fumigants. Baccari et al., (2020) reported that Ferula tunetana Pomel ex Batt. Essential oils had insecticidal activity against Tribolium castaneum Herbst. The essential oils used as fumigants showed $93 \%$ repellency and toxicity against $T$. castaneum at $161.89 \mu \mathrm{L} \mathrm{L/L}$ $\mathrm{LD}_{50}$ value. Bagheri and Rahimi (2014) observed that the Ferula assa-foetida H.Karst. essential oil had a valuable effect on the mortality rate of the black bean aphid at $1 \%$ probability level. The highest mortality rate (13.5) in aphids was reported at $300 \mu \mathrm{L} / \mathrm{ml}$ (leaf essential oil) and $500 \mu \mathrm{L} / \mathrm{ml}$ (seed essential oil) oil concentration, compared to the control (1.5). Furthermore, Goldansaz et al., (2012) evaluated the insecticidal activity of $F$. assa-foetida essential oil against carob moth (Ectomyelois ceratoniae) a polyphagous pest of pomegranate. All concentrations used in the experiment (oil: solvent, 1:1, 1:3, and 1:5), showed significant inhibition of insect with $p<$ 
TABLE 2 | Tested living system, different bioactivities and major chemical components of the essential oil from different species of Ferula genus growing in different countries.

\section{Plant name (province) Used plant part (extraction method); essential oils major components

Ferula assa-foetida L. (Iran) Gum (HD)

Seeds (soxhlet)

Cytotoxic

Antinociceptive

Relaxant

Gum (HD); 1-(2-methyl-1,3-oxathiolan-2-yl) ethanone, (thiophene, trans-dibenzylideneacetone and (Z)-propenyl sec butyl disulfide Dleo-gum resin (HD)

Vasorelaxant

Antiprotozoan

Antimicrobial

Oleo-gum-resin (HD); OGR1: 10-Epi-c-eudesmol and (E)-1-propenyl sec-butyl disulfide; OGR2: (E)-1-propenyl sec-butyl disulfide (Z)-1-propenyl secbutyl disufide; OGR3: $\alpha$-pinene and. $\beta$-pinene

Air-dried leaves latex (HD); E-1-propenyl-sec-butyl Scolicidal disulfide, $\beta$-pinene and $\beta$-ocimene
Herbaceous plant (HD)

Insecticidal

Dried aerial parts $(\mathrm{HD})$

Insecticidal

Gum (HD); (E)-1-propenyl sec-butyl disulfide, $\beta$-pi- Insecticidal nene, (E)- $\beta$-ocimene, (Z) $-\beta$-ocimene and $\alpha$-pinene Gum (HD)

Insecticidal

Latex (HD)

Foliar parts (HD)

Gum (HD); (E)-1-propenyl sec-butyl disulfide, (Z)-1propenyl sec-butyl disulfide and 10-epi- $\gamma$-eudesmol Seeds and oleo-gum-resin (HD); (E)-1-propenyl secbutyl disulfide and (Z)-1-propenyl sec-butyl disulfide Resin $(H D)$; guaiol (13.66\%) and $\beta$-Pinene

Antimicrobial

Dried plant materials $(\mathrm{HD})$

Antifungal
Rhyzopertha dominica
Breast cancer $4 \mathrm{~T} 1$ cells

Male albino mice

Male wistar rats ileum

Result showed that all constituents of essential oil Bagheri et al., (2017a) could inhibit 4T1 cell proliferation in time and dose dependent manner

Exhibited valuable antinociceptive activity on acute Bagheri et al., (2017b) and chronic pain in mice

Seed and assa-foetida essential oils $(0.3 \%$ and Bagheri et al., (2014a) $0.2 \%$ ) could be significantly decrease ach

$\left(10^{-4} \mathrm{M}\right)$ induced contractions by $35.6(4.12)$ and $8(2.4), p=0.03 ; 43 \%$ and $12 \%, p=0.02$, respectively

Rats' thoracic aorta

AEO showed a significant vasodilatory effect which could be endothelium-independent or dependently

AEO displayed relaxant effect on the precontracted rings, dose-dependently at $23 \mu \mathrm{L} / \mathrm{L} \mathrm{IC}_{50}$ value

The lowest and highest percentage inhibition value El Deeb et al., (2012)

at which Blastocystis showed no growth and multiplication were 16 and $40 \mathrm{mg} / \mathrm{ml}$

Blastocystis sps Gram-negative bacteria: Escherichia coll PTCC 1330 and MIC (minimal inhibitory concentration) for gram- Kavoosi and Rowshar
Salmonella typhi PTCC 1609; foodborne gram-positive negative and positive bacteria and fungi were (2013), Kavoosi et al.,

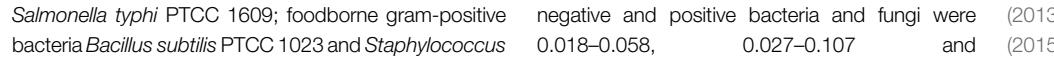
aureus PTCC 1112; foodborne fungi: Candida albicans $\quad 0.028-0.111 \mathrm{mg} / \mathrm{ml}$ of essential oil, obtained from PTCC 5027 and Aspergillus niger PTCC $5010 \quad$ OGR3, OGR2 and OGR1, respectively

Echinococcus granulosus $\quad$ Results indicated that 10 min exposure of $F$. assafoetida essential oil with $60 \mu \mathrm{g} / \mathrm{ml}$ or more concentration were killed all protoscolices

Ectomyelois ceratoniae

Callosobruchus maculatus

Aphis gossypii

Agonoscena pistaciae

All concentration showed complete inhibition of pest

F. assafoetida L (150 uL) showed 100\% mortality against adult $C$. maculatus, respectively

0.04 th appeciable insectidial activity at

$0.04 \mu \mathrm{L} / L \mathrm{LC}_{50}$ value and repellant activity at $\mu \mathrm{L} / \mathrm{mL}$ with $65.71 \mathrm{~h}$ persistence

$\mathrm{LC}_{50}$ values of essential oil were obtained Izadi et al., (2012) $5.62 \mathrm{mg} / \mathrm{L}$

Pseudomonas aeruginosa Chromobacterium violaceum

Essential oil caused reduction in pyocyanin, pyoyerdine, elastase, biofilm and homoserin lactones (HSL) production in $P$. aeruginose and also inhibited violacein production in C. violaceum

$4 \mu \mathrm{L} / \mathrm{ml}$ concentration of tested essential oil com pletely inhibited biofilm formation

Candida albicans, C. dubliniensis, C. krusei

Lactobacillus rhamnosus, Streptococcus sobrinus, S. The -resin oil had strongest antibacterial properties mutans, S. salivarius and S. sanguis

$\beta$-Lactamase producing Acinetobacter baumannii than the seed oil $(p<0.001)$ Showed antibacterial effect with $18.75 \mathrm{mg} / \mathrm{ml}$ MIC value

Penicillium digitatum and $P$. italicum with conidia germination and germ tube elongation inhibition 
TABLE 2 | (Continued) Tested living system, different bioactivities and major chemical components of the essential oil from different species of Ferula genus growing in different countries

\section{Plant name (province) Used plant part (extraction method); essenta} oils major components

Ferula assa-foetida L. (India) Stem and root (HD); (E) and (Z) sec-butyl propenyl Ovicidal and larvicidal Larvae of Culex pipiens and Culex restuans disulfide and methyl 1 -(methythio) propyl

Latex (HD)

Anti-quorum sensing

Chromobacterium violaceum
Latex (HD); $\boldsymbol{\beta}$-pinene, and 1,2-dithiolane and $\boldsymbol{\alpha}$-pinene

Gum (HD); pathani: 1-(1- propenytthio) propyl methyl Antifungal and disulfide and (E)-1 - propenyl sec butyl disulphide; irani: antibacterial (E)-1- propenyl sec-butyl disulfide and (Z)-1 - propeny sec-butyl disulfide

Resin (soxhlet)

Ferula aucheri boiss. Piwc- Dried flowering tops, fruits, and roots (HD); $\beta$-caryozynski, spalik, M. Panahi phyllene and germacrene B (roots); $\delta$-cadinene (flowand puchalka (Iran) ering tops); gurjunene and $\boldsymbol{\delta}$-cadinene (fruit)

Ferula assafoetida L. (kakan) Leaves and seeds (HD)

Ferula communis L. (Tunisia)

Aerial parts $(H D) ; \boldsymbol{\beta}$-caryophyllene, $\boldsymbol{\beta}$-myrcene, $\boldsymbol{\alpha}$-pinene, $\boldsymbol{\alpha}$-eudesmol, $\boldsymbol{\gamma}$-curcumene, $p$-menth $\boldsymbol{\alpha}-1,5$-dien8 -ol and $\gamma$-eudesmol

Flowers, leaves, stems, and roots (HD); camphor, Antibacteria $\boldsymbol{\beta}$-eudesmol, and $\boldsymbol{\alpha}$-pinene (flower); $\boldsymbol{\beta}$-eudesmol, aeudesmol and $\boldsymbol{\delta}$-eudesmol (Stems); dillapiole, guaiol an spathulenol (roots); $\boldsymbol{\alpha}$-eudesmol, deudesmol an $\beta$-eudesmol (leaf)

Ferula communis L. (Turkey)

Aerial parts $(\mathrm{HD})$

Ferula cupularis boiss. (Iran) $\quad$ Flower leaves stem (HD); $\boldsymbol{\delta}$-2-carene (flower); $\boldsymbol{\beta}$-ocimene and $\boldsymbol{\beta}$-pinene (leaf); $\boldsymbol{\delta}$-3-carene and $\boldsymbol{\alpha}$-terpiny isobutyrate (stem)

Ferula edeechytris korovin Fruts (HD); $\boldsymbol{\alpha}$-pinene, $\boldsymbol{\beta}$-phellandrene and sabinene (France)

Ferula ferulaeoides (steud.) Root (HD)

korov. (China)

$$
\text { Root (HD) }
$$

Insecticidal

Ferula galbaniflua boiss. and Leaves and stems (HD); methyl-8-pimaren-18-oate Antiprotozoan buhse. (Brazil)
Antifungal and antibacterial

Antifungal

Insecticidal

Salmonella typhi, E. coli, S. aureus, B. subtilis, A. niger, and $\mathbf{C}$. albicans

Aspergillus niger, A. flavus, $\boldsymbol{A}$. ochraceus, Fusarium oxysporum, $P$. chrysogenum, S. aureus, Yersinia enteroco-
litica, Salmonella paratyphi, S. typhi, Bacillus subtilis, $\boldsymbol{B}$. litica, Salmonella paratyphi, S. typhi, Bacillus subtilis, $\boldsymbol{B}$.
cereus, Escherichia coli and Listeria monocytogenes

Alternaria alternata, A. solani, A. flavus, A. niger, A. wentii, Rhizoctonia spp. Drechslera tetramera, $D$. hawaiiensis, Fusarium semitectum, F. moniliforme and F. solani: Isolated from okra seeds

Pseudomonas aeruginosa, E. coli, Staphylococcus epidermidis, S. aureus, Bacillus subtilis, K. pneumonia, Shigella dysenteriae, Salmonella paratyphi, Proteus vulgaris, Candida allbican, Aspergillus brasiliensis and A. niger

Black bean aphid

Leishmania infantum and Leishmania (L.) major promastigotes

Pseudomonas aeruginosa

Antibacterial

Chryseobacterium indologenes

Staphylococcus epidermidis, S. aureus, B. subtilis, coli, $\boldsymbol{K}$. pneumonia

S. aureus, E. coli, yeast, C. parapsilosis, C. albicans, Cryptococcus neoformans, T. violaceum, T. soudanense, $T$. rubrum, T. mentagrophytes, $T$. tonsurans, $A$. spergillus and $A$. fumigatus

Plutella xylostella, Mythimna separate and Mus domestica

Leishmania amazonensis
Result showed Culex restuans ( $L \mathrm{C}_{50}: 10.1 \mathrm{mg} / \mathrm{L}$ ) Muturi et al., (2018) more sensitive to essential oil than Cx. Pipiens. The eggs exposed to essential oils were (55.8\%) failed to hatch

Essential oil reduced the production of violacein Khambhala et al., (2016) and pyocyanin in $C$. violaceum and $P$. aeruginosa, respectively

MIC values $90 \pm 11,85 \pm 5,80 \pm 12,125 \pm 17$ $>200$, and $>200, \mu \mathrm{g} / \mathrm{mL}$ were reported for S. typhi E. coll, C. albicans, S. aureus, B. subtilis, $\boldsymbol{A}$. niger, S. aureus and $\boldsymbol{B}$. subtilis, respectively

Essential oil from pathani and irani $F$. assa-foetida Exshibited a good antibacterial (Bacillus subtilis and exhibited a good antibacterial (Bacillus subtilis and
Escherichia coll) and antifungal (Aspergillus ochraEscherichia coll) and antifungal (Aspergillus ochra-
ceus and Penicillium chrysogenum) activity, ceus and Penicillum chrysogenum) activity, respectively

Sitara et al., (2018) of essential oil concentration

Exhibited lower MICs value for Klebsiella pneumonia, Bacillus subtilis, Salmonella paratyphi-A serotype and Shigella dysenteriae compared to gentamicin, whereas fruit and root oils were most efficient against $E$. coli compared to gentamicin Highest death (13.5) rate in essential oil treated black bean aphid was reported than the control (1.5)

Caryophyllene had high leishmaniacidal activity Essid et al., (2015) against $L$. major $(1.33 \pm 0.52 \mu \mathrm{g} / \mathrm{ml})$ and $L$. infantum $(1.06 \pm 0.37 \mu \mathrm{g} / \mathrm{m})$

The best results were showed by the essential oil of Nguir et al., (2016) leaves against $P$. aeruginosa (MIC value $0.156 \mathrm{mg} / \mathrm{mll}$

Result showed the essential oil had a great poten- Dadaşoğlu et al,,(2018) tial to control $C$. indologenes

Showed 22.75, 5.69 and $2.85 \mathrm{mg} / \mathrm{ml}$ MIC value of Alipour et al.. (2015)

flower, leaf and stem (except $P$. aeruninos) eslowner, Presen olls anainst tested gam. positive bacteria coccus aureus Trichophyton species

Guaiol showed great contact inhibition of Plutella xylostella and Mythimna separate at $\mathrm{LD}_{50}$ values: 8.9 and $0.07 \mathrm{mg} / \mathrm{arva}$, respectively whereas, fumigation activity against the $M$. domestica and $M$. separata, were observed at $\mathrm{LC}_{50}$ values of $16.9 \mu L / L$ and $3.5 \mu L / L$, respectively

Essential oil had potent effect on against Leish- Andrade et al., (2016) mania amazonensis and its $1 \mathrm{C}_{50} / 24 \mathrm{~h}$ value was $54.05-162.25 \mu \mathrm{g} / \mathrm{ml}$ 
TABLE 2 | (Continued) Tested living system, different bioactivities and major chemical components of the essential oil from different species of Ferula genus growing in different countries Plant name (province)

Ferula gummosa boiss. (Iran) Gum (HD); a-pinene, carvacrol methyl ether, $\boldsymbol{\delta}-3-\quad$ Cytotoxic carene and $\boldsymbol{\beta}$-phellandrene

Gum (market product)

Hypoglycemic and

hypolipidemic

L929 mouse fibroblast cells

Male wistar rats

Market product

Insecticidal

Gum (HD)

Insecticidal

Root (HD)

Insecticidal

Aerial part (HD)

Resin (market product)

Antibacteria

Antibacterial

Resin (HD)

Antibacterial

Resin $(\mathrm{HD})$; $\boldsymbol{\alpha}$ - pinene, $\boldsymbol{\beta}$-pinene and $\boldsymbol{\delta}$-3-

Acaricidal

Ferula haussknechtii H. Wolff Root and aerial parts (HD); camphene, isoverbanol and Antibacteria ex rech. f. (Iran) a-pinene

Ferula hermonis boiss. Root and rhizome (HD); $\boldsymbol{\alpha}$-bisabolol, $\boldsymbol{\delta}$-cadinene and. Antifunga (France) $\beta$-farnesene

Ferula heuffelii griseb. Ex Underground part (HD); elemicin, phenyl propanoids, heuff. (Serbia) myristicin and $\boldsymbol{\alpha}$-pinene

Antibacterial and anticandidal

Ferula lycia boiss. (Turkey)

$\boldsymbol{\alpha}$-pinene, bornyl acetate, limonene and $\boldsymbol{\beta}$-Pinene

Antibacteria

Ferula lutea (poir.) maire. Roots (HD); delta-3-carene, $\boldsymbol{\alpha}$-pinene, $\boldsymbol{\beta}$-myrcene and Cytotoxic (Tunisia) $\alpha$-phellandrene

Ferula lutea (poir.) maire. Roots (HD); delta-3-carene, alpha-phellandrene, myr- Antibacteria (France)
Bemisia tabaci and Orius albidipennis

Callosobruchus maculatus

Ephestia kuehniella

Enterococcus faecalis, Streptococcus sobrinus, S. salvarius and $S$. mutans

Staphylococcus aureus

Pseudomonas aeruginosa

Tetranychus urticae

Bacillus cereus, B. subtilis, B. pumilus, E. coli, S. epiBacillus cereus, B. subtis, B. pumilus, $\boldsymbol{E}$. colli, S. ept permidis, $\boldsymbol{K}$.

Aspergillus fumigatus, A. niger, Candida albicans, Microsporum gypseum, Penicillium purpurogenum, Sacch romycescerevisiae andTrichophyton mentagrophytes Gram-positive bacteria: Staphylococcus aureus, S. epidermidis, Micrococcus luteus, Bacillus subtilus and $\boldsymbol{B}$ cereus; gram-negative bacteria: Salmonella typhimurium, Pseudomonas aeruginosa and Escherichia coll; fungi: Candida glabrata, $C$ albicans, $\boldsymbol{C}$. tropicalis and $\boldsymbol{C}$. sake Staphylococcus epidermidis, S. aureus, Enterococcus faecalis, E. cloacae, Klebsiella pneumonia, Escherichia coli, Serratia marcescens, Salmonella typhimurium, Proteus vulgaris, Haemophilus influenza and Pseudomonas aeruginosa

Human colon cells (HT-29 and HCT-116 cells)

Staphylococcus epidermidis, S. aureus, Micrococcus Iuteus, Bacillus cereus, $\boldsymbol{B}$. subtilus, $\boldsymbol{E}$. colli, P. aeruginosa Salmonella typhimurium, Candida albicans, C. glabrat c. tropicalis

Gram-negative bacteria: Salmonella typhimurium Pseudomonas aeruginosa and Escherichia coll; gram-positive bacteria: Staphylococcus aureus, S. epidermidis Micrococcus luteus, Bacillus subtilis and $\boldsymbol{B}$. cereus;Candida glabrata, $\boldsymbol{C}$. albicans, $\boldsymbol{C}$. tropicalis and $\boldsymbol{C}$. sake
The average cell viability of L929 cells were ob- Abbaszadegan et al served about $88 \%$ at full concentration $(50 \mu \mathrm{L} / \mathrm{ml}) \quad$ (2015) of the essential oil

Glucose, triglyceride, cholesterol LDL-C and HDL- Karimlar et al., (2019) C IC $\mathrm{C}_{50}$ values for $F$. gummosa were recorded as $429.91 \pm 46.14,105.18 \pm 12.13,91.02 \pm 11.95$, $29.59+3.76,42.07+9.68(\mathrm{mg} / \mathrm{dl})$, respectively For Bemisia tabaci, $0.059 \mathrm{LL}^{-1} \mathrm{D}_{50}$ value was observed along with significant effect against $O$. albidipennis

The essential oil showed $100 \%$ death rate at $500 \mu\llcorner/ L$ after $6 \mathrm{~h}$ exposure interva

Topical application presented drastic reduction in total hemocyte count

The MIC value $1.0125 \mu \mathrm{g} / \mathrm{ml}$ was reported for faecalis and other strains

Showed the best antibacterial activity against methicilin resistant $S$. aureus (MRSA) and methicillin sensitive (MSSA) bacterial strains

Revealed the significant antibacterial activity of Satarian et al., (2018) plant essential oils and extracts $(p<0.001)$

Essential oil displayed high toxicity on adults and Fatemikia et al., (2017)

eggs of $T$. urticae with $L_{50}$ value 6.52 and

$6.98 \mu \mathrm{L} / \mathrm{L}$, respectively

Essential oil exhibited efficient activity against Staphylococcus aureus, Staphylococcus epidermidis and Bacillus pumilus at $7.5 \mathrm{mg} / \mathrm{ml}$ concentration: 17-18 mm growth inhibition

Essential oil exhibited the strongest antifungal Al-Ja'fari et al., (2011) activity against $T$. mentagrophytes

Displayed antimicrobial potential against two Juglal et al., (2002) strains of Micrococcus luteus, Staphylococcus Pavlović et al., (2012) epidermidis, Micrococcus flavus and Candida albicans; MIC value 13.7, 13.7, 17.6, 21.1, 28.2 and $7.0 \mu \mathrm{g} / \mathrm{ml}$, respectively

Haemophilus influenzae ATCC 49247 was re- Kose et al., (2010)

ported as the most sensitive bacteria among all tested one with $14 \mathrm{~mm}$ inhibition zones

The $\mathrm{IC}_{50}$ values were $26.39 \pm 3.98 \mu \mathrm{g} / \mathrm{ml}$ and Ben et al.. (2016) $81.00 \pm 12.81 \mathrm{~kg} / \mathrm{ml}$ for $\mathrm{HT}-29$ and $\mathrm{HCT}-116$ respectively

(2016)

candidal activity against E. coli, Salmonella typhimurium, Candida albicans with MIC value; 39, 78 and $156 \mathrm{mg} / \mathrm{ml}$, respectively

Exhibited antibacterial and anticandidal activity Znati et al., (2012) against S. epidermidis, S. aureus and E. coli $(\mathrm{MIC}=39 \mu \mathrm{g} / \mathrm{m})$ ); and C. albicans (MIC =

$156 \mu \mathrm{g} / \mathrm{ml})$ 
TABLE 2 | (Continued) Tested living system, different bioactivities and major chemical components of the essential oil from different species of Ferula genus growing in different countries

Plant name (province) Used plant part (extraction method); essential oils major components

Ferula orientalis L. (Turkey) Stem (soxhlet); a-pinene, terpinolene, o-cymene, Neuroprotective $\beta$-caryophyllene, limonene and bornyl acetate Aerial parts $(\mathrm{HD}) ; \boldsymbol{\alpha}$ and $\boldsymbol{\beta}$-Pinene

Antimicrobial

Ferula ovina (boiss.) boiss

Aerial parts (HD); $\boldsymbol{\alpha}$-pinene, camphene, sabinene, $\boldsymbol{\beta}$-pinene, sabinene, myrcene and dehydro-1, 8-cineole Dried root (HD)

Antinociceptive hyperalges Insecticidal

Cytotoxic

Ferula persica willd. (Iran)

Gum (HD); alpha-pinene, (Z)-1-propenyl sec-buty/ disulfide $\boldsymbol{\beta}$-pinene, $\boldsymbol{\beta}$-dihydroagarofuran, allo-aromadendrene, (Z)- $\beta$-ocimene, $\quad \beta$-dihydrobenzofuran, $\boldsymbol{\alpha}$-caryophyllene and (E)-1-propenyl sec-butyl disulfid

Ferula tadshikorum pimenov. Underground parts (HD); (Z)-sec-butyl propenyl disul(Tajkistan)

fide, (E)- sec-butyl propenyl disulfide and (E)-1-propenyl 1-(methylthio)propyl disulfide

Underground (HD); (E)-1-propenyl sec-butyl disulfide, Antibacteria (Z)-1-propenyl sec-butyl disulfide, and (E)-1-propeny 1 -(methylthio)propyl disulfide

Ferula tingitana L. (Egypt) $\quad$ Flowers and leaves (HD); $\boldsymbol{\alpha}$-thujene, eudesmol, elemol Antitumor and cadino

Ferula tunetana pomel ex Seed oil (HD); $\boldsymbol{\alpha}$-pinene, myrcene, (Z)- $\boldsymbol{\beta}$-ocimene, $\boldsymbol{\beta}$-pi- Antigerminative batt. (Tunisia) nene, $\boldsymbol{\beta}$-phellandrene and limonen Seed (HD); $\boldsymbol{\alpha}$-pinene, (Z)- $\boldsymbol{\beta}$-ocimene and $\boldsymbol{\beta}$-pinen

Antimicrobial

Flower (HD); $\boldsymbol{\alpha}$-Pinene, epi- $\boldsymbol{\alpha}$-muurolol, $\boldsymbol{\beta}$-chenopodiol Insecticidal and himachalol

Ferula vesceritensis coss. Flowers and stems (HD); $\boldsymbol{\alpha}$-pinene, $\boldsymbol{\beta}$-pinene, elixene Antibacteria and durieu ex trab. (Algeria) $\quad \boldsymbol{a}$-phellandrene, aristolene and fenchylacetate

Ferula vesceritensis coss. Dried leaves (HD); shyobunol, (t-cadinol, $\boldsymbol{\delta}-3$-cadinene, Insecticidal and durieu ex trab. (East of $\mathbf{\alpha}$-cadinol and aristolene

algiers)

Ferula vesceritensis coss. Dried aerial parts (HD); germacrene D, 5, 9-tetrade- Antibacterial and durieu ex trab. (Algeria) cadiyne, $\boldsymbol{a}$-bisabolene and farnesen

Tested living system

\section{Cortex neuron cells}

Staphylococcus aureus, Escherichia coll, Pseudomonas aeruginosa and Candida albicans

and Mice and other animals

Sesamia cretica

Vero cell, murine colon carcinoma (CT26) cell lines

CEM/ADR5000 and CCRF-CEM cell lines

Methicillin-resistant Staphylococcus aureus, Escherichia

Hormone-responsive MCF7 breast cells, liver carcinoma HePG2) cells, and cervical (HeLa) cels

Bacteria: Staphylococcus aureus, Bacillus subtilis, Streptococcus faecallis, Escherichia colli, Pseudomonas aeruginosa and Neisseria gonorrhea: fungi: Candida albicans, Aspergillus flavus

Medicago sativa, Triticum aestivum and Lactuca sativa

ram (+) bacteria: Staphyllococcus aureus ATCC 25923 and CIP106510, Bacillus subtilus ATCC 6633, B. cereus ATCC 14579, ATCC 11778 and M. luteus NCIMB 8166; gram (-) bacteria: Escherichia coll ATCC 25922, ATCC 35218, Salmonella typhimurium ATCC 13311, LT2DT104; Pseudomonas aeruginosa ATCC 27853, Candida albicans ATCC 90028 and C. glabrata ATCC 90030

Tribolium castaneum

Pseudomonas aeruginosa, Enterobacter aerogenes, E. coli, S. aureus, Klebsiella pneumonia, Morganella

Sitophilus oryzae

Escherichia coli, Staphylococcus aureus and Klebsiella pneumonia
Essential oils fractions displayed 93\% repellent Baccari et al., (2020) activity

Essential oil at $10^{-2}$ concentration showed signif- Topdas et al., (2020) icant neuroprotective activity

The oil of $F$. orientalis aerial parts was active against Karakaya et al., (2019a) Candida albicans and Staphylococcus aureus

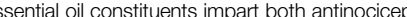
ive and hyperalgesic potentially

Each concentration found to have significant effect on the immune ability of Sesamia cretica

The viability was decreased in essential oil treatedVero cell $\left(0.125 \times 10^{-9}\right.$ to $80 \mu \mathrm{L} / \mathrm{mll}$ ) and CT26 cell ine $\left(0.125 \times 10^{-9}\right.$ to $\left.20 \mu \mathrm{L} / \mathrm{ml}\right)$, dose dependently

Displayed 142.5 and $21.6 \mu \mathrm{g} / \mathrm{ml}, \mathrm{IC}_{50}$ values for CEM/ADR5000 and CCRF-CEM cell lines, respectively

(2019) bacterial activity up to $20 \mathrm{mg} / \mathrm{ml}$ concentration

$\mathrm{C}_{50} \%$ value for in vitro cytotoxicity of flower and eaves essential oil against liver (HEPG2) carcinoma cell, cervical (HELA) and breast (MCF7), lines were as follows: 4, 4, 42:8,6, 10.9 and 6.9, $4,8, \mu g / m$ respectively

(enced most efficient antibacterial activity again Neisseria gonorrhoeae and Bacillus subtilis with 41.9 and $48.3 \%$ potency compared to tetracycline

Germination of seedlings were completely inhibited $10 \mathrm{mg} / 5 \mathrm{ml}$ and $20 \mathrm{mg} / 5 \mathrm{ml}$ concentration

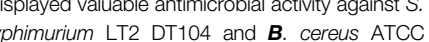

4579 (inhibition zone 16.2-1.0 and 15.8-1.0

$\mathrm{mm}$, respectively)

Contact and inhalation methods showed potent Benchabane (2014) insecticidal activity with $\left(\mathrm{LD}_{50}=16.4 \mu \mathrm{L} / \mathrm{ml}, \mathrm{LD}_{90}=\right.$ $5.45 \mu \mathrm{L} / \mathrm{ml}$ values

The essential oil presented appreciable growth Zellagui et al., (2012) inhibition of listed bacteria 
0.001. In another study, Estekhdami et al., (2020) also evaluated the insecticidal activity of $F$. assa-foetida essential oil against Callosobruchus maculatus in an interval of 8,24 , and $48 \mathrm{~h}$, respectively. F. assa-foetida essential oil was used with 0,30 , $60,90,120$, and $150 \mu \mathrm{L}$ concentration and a death rate reported at $8,24,48 \mathrm{~h}$ intervals. The mortality rate was observed to be $100 \%$ at a $30 \mu \mathrm{L}$ concentration. Fumigant toxicity and persistence of the essential oil of $F$. assa-foetida with two others were investigated against adult insects (Rhyzopertha dominica F.). The result suggests that $F$. assa-foetida essential oil has more toxicity against $R$. dominica compared to other tested plants. The halflife of the essential oil of asafoetida was reported to be $65.71 \mathrm{~h}$ which is also greater than the others (Bahrami et al., 2016). Hosseinpour et al., (2011) investigated the fumigant insecticidal activity of two plants including galbanum (F.gummosa) essential oils extracted from the gum with a Clevenger apparatus. The fumigant insecticidal activity of essential oils was examined alongside adult Callosobruchus maculatus (1-7 days old) with different concentrations ranging from 7.1 to $57.1 \mu \mathrm{L} / \mathrm{L}$ air, at $27-28^{\circ} \mathrm{C}$ room temperature, $65-70 \%$ relative humidity and in dark conditions. Galbanum oil presented a $47.5 \%, 80 \%$, and $100 \%$ mortality rate at $500 \mu \mathrm{L} / \mathrm{L}$ (air) after 2,4 , and $6 \mathrm{~h}$ exposure intervals, respectively.

Liu et al., (2013) evaluated an insecticidal sesquiterpene guaoil, found in the essential oils of many plants. To examine the insecticidal property of the compound, three insect larvae were used, namely Mythimna separata Walker, Plutella xylostella L., and Musca domestica L. An effective contact inhibition was observed in the 4th instar larvae of Mythimna separata and third instar larvae of $P$. xylostella at 0.07 and $8.9 \mathrm{mg} / \mathrm{larva}$ concentrations of guaoil while using the fumigation method, the growth inhibition was observed at 3.5 and $16.9 \mu \mathrm{L} / \mathrm{L}$ guaoil concentration, respectively. Koorki et al., (2018) tested F. assafoetida essential oil along with two other medicinally important plants to find their toxicity against Aphis gossypii Glover which has caused economic losses in tested medicinal plants. Lethal concentrations $\left(\mathrm{LC}_{50}\right)$ of the essential oil of $F$. assa-foetida were examined after $12(9.04 \mu \mathrm{L} / \mathrm{L}$ air $)$ and $24(4.64 \mu \mathrm{L} / \mathrm{L}$ air $)$ hours whereas at a $10 \mu \mathrm{L} / \mathrm{ml}$ concentration the essential oil showed repellent activity. The chemical composition of the essential oil was also evaluated by GC-MS and the major chemical components were (E)-sec-butyl propenyl disulfide (Z) and (E)$\beta$-ocimene, $\beta$ and $\alpha$-pinene. The effect of essential oils from $F$. assa-foetida L. with some other plant species was studied on the growth and physical fitness of Trichogramma embryophagum (Hartig) and Trichogramma evanescens (West.) - parasitoids on the eggs of carob moths. Essential oils at 877 ppm (LC01) exhibited a significant reduction in longevity, wing normality, development, female's fecundity, the sex ratio of their progeny, and survivorship (Poorjavad et al., 2014).

\section{ANTIQUORUM SENSING AND ANTIBIOFILM ACTIVITY}

Sepahi et al., (2015) evaluated the potential of F. assa-foetida essential oil to inhibit the quorum sensing in Pseudomonas aeruginosa. The essential oil $(25 \mathrm{mg} / \mathrm{ml})$ presented antiquorum activity and fully abolished pyocyanin, pyoyerdine, elastase, biofilm, and homoserine lactone (HSL) production. F. assa-foetida essential oil mediated las system inhibition was observed in Chromobacterium violaceum. Since the violacein production is related to the las system, violacein production inhibition was also observed in $F$. assa-foetida essential oil treated C. violaceum. The chemical profile of the essential oil extracted from the resin of $F$. assa-foetida, antibiofilm and antimicrobial activity were also investigated by Zomorodian et al., (2018). The main components of essential oil analyzed by the GC/MS method, contained $21.65 \%$ of (E)-sec-butyl propenyl disulfide and $19.5 \%$ of (10-epi- $\gamma$-eudesmol and $10.20 \%$ of 2 -[(Z)-prop-1-enyl] disulfanyl] butane. The essential oil exhibited partial inhibition (50\%) of the biofilm formation in the standard strains of Candida krusei, C. tropicalis and C. albicans at concentrations of $0.06,0.125$, and $0.25 \mu \mathrm{L} / \mathrm{ml}$, respectively. However, the essential oil showed $100 \%$ inhibition of biofilm formation at $4 \mu \mathrm{L} / \mathrm{ml}$ of concentration.

\section{ANTIMICROBIAL ACTIVITY}

It has been reported that the essential oils obtained from the root and rhizome of the Ferula hermonis Boiss. had a significant effect on many fungal strains such as dermatophytes namely Trichophyton mentagrophytes (Al-Ja'fari et al., 2011). The main chemical components of the essential oil analyzed by GC-MS and FID, and 13C NMR were $\alpha$-bisabolol, $\beta$-farnesene, and $\delta$-cadinene. The MIC and MFC values of essential oils for $T$. mentagrophytes were reported to be $8 \mu \mathrm{g} / \mathrm{ml}$ and $10.25 \mu \mathrm{g} / \mathrm{ml}$ for 3, 5-nonadiyne and JB73, respectively. In a study, the antibacterial activity of hydrodistilled essential oil from fresh stems (FS), fresh flowers (FF), and dry stems (DS), dry flowers (DF) of Ferula vesceritensis Coss. \& Durieu ex Trab. were demonstrated. The essential oils possessed $\alpha$ and $\beta$-pinene, $\alpha$-phellandrene as abundant chemical constituents along with a minute amount of caryophyllene oxide, aristolene, carotol, and elixene (Kim et al., 2004). Nine strains of foodborne and clinically isolated bacteria including Escherichia coli, Morganella morganii, Klebsiella pneumonia, Pseudomonas aeruginosa, Staphylococcus aureus, and Enterobacter aerogenes were used for the antibacterial activity analysis. The minimum inhibitory concentration (MIC) was reported at a concentration of $128 \mu \mathrm{g} / \mathrm{ml}$ against almost all foodborne pathogens and clinical isolates, whereas for the others the concentration was $16-80 \mu \mathrm{g} / \mathrm{ml}$ (Labed-Zouad et al., 2015). Satarian et al., (2018) also tested the extract and essential oils of Ferula gummosa for their antibacterial activity against clinically isolated from $P$. aeruginosa. In another study, bactericidal activity of essential oil from $F$. assa-foetida was reported by Kavoosi et al., (2013) together with some other activity including antioxidant, antiseptic, sedative, antispasmodic, analgesic, and carminative activity. The essential oils comprised pinene ( $\beta$ : 47.1\%; $\alpha: 21.36 \%)$ and 1,2dithiolane $(18.6 \%)$ as main compounds which showed a minimum inhibitory value at the concentration of $90 \pm 11$, $85 \pm 5,80 \pm 12,125 \pm 17,>200$ and $>200 \mu \mathrm{g} / \mathrm{ml}$ against the 
tested strains namely Candida albicans, Aspergillus niger, Bacillus subtilis, Staphylococcus aureus, Escherichia coli, and Salmonella typhi, respectively. The antifungal and antibacterial activity of the flower oil of Ferula elaeochytris Korovin along with some other plant species was demonstrated against some selected Grampositive, Gram-negative bacteria and fungal strains (Khoury et al., 2018). The essential oil was found to have the most antibacterial activity against the Staphylococcus aureus and dermatophytes (Trichophyton species) with a $8-64 \mu \mathrm{g} / \mathrm{ml}$ MIC value. The $F$. haussknechtii essential oil, which was extracted by the Clevenger apparatus contained camphene, $\alpha$-pinene, and isoverbanol as abundant chemical constituents; these compounds exhibited antibacterial activity against nine bacterial strains. The result showed that Bacillus pumilus, Staphylococcus epidermidis and S. aureus were more sensitive to the essential oil among other tested bacterial strains (Arjmand and Dastan, 2020). Alipour et al., (2015) enumerated the bactericidal activity of the essential oil acquired from stem, leaf, and flower parts of the Ferula cupularis Boiss. against some Gram-positive bacteria. The main components that were analyzed by the GC-MS analysis displayed a great variation. The MIC value of flower, leaf, and stem (except $P$. aeruginosa) oils were $22.75 \mathrm{mg} / \mathrm{ml}, 5.69 \mathrm{mg} / \mathrm{ml}$, and $2.85 \mathrm{mg} / \mathrm{ml}$ against tested Gram-positive bacteria. Ferula gummosa oil showed antibacterial potential against Enterococcus faecalis, Streptococcus sobrinus, S. salivarius, S. mutans with a $1.0125 \mathrm{mg} / \mathrm{ml}$ MIC value (Nazemisalman et al., 2018). Divya et al., (2014) investigated the antimicrobial activity of essential oils from two plant varieties (Pathani and Irani) of $F$. assa-foetida, against various food-borne bacterial and fungal species. Different types of plant varieties also possessed variations in their oil chemical profiles. In accordance with the result, a conclusion was made that the essential oil of the Pathani F. assa-foetida variety exhibited a good antibacterial activity (Escherichia coli and Bacillus subtilis); whereas, the essential oil of Irani the F. assa-foetida variety exhibited good fungicidal activity (Penicillium chrysogenum and Aspergillus ochraceus). Furthermore, a study revealed the antimicrobial properties of the essential oil of the resin and seed of $F$. assa-foetida against various oral bacteria such as Lactobacillus rhamnosus, Streptococcus salivarius, Streptococcus sanguis, Streptococcus sobrinus, and Streptococcus mutans (Daneshkazemi et al., 2019). The resulting analysis displayed that the oleogum-resin essential oil had significant and effective antibacterial activities as compared to the seed essential oil ( $p<0.001)$. Jahani et al., (2015) reported the antibacterial activity of gelatin nano-capsules formulated from the essential oil of $F$. assa-foetida. Mallahi et al., (2018) studied the potential of Ferula essential oil to increase the shelf-life of Gerbera jamesonii (Gerbera Daisy) flower by inhibiting the pathogenic bacteria. Ahmadi et al., (2020) tested F. aucheri essential oil for its antimicrobial potential. All aerial parts of the plant used to extract oil had different major chemical components. All essential oils exhibited lower MIC for Salmonella paratyphi-A serotype, Shigella dysenteriae, Klebsiella pneumonia, and Bacillus subtilis but gentamicin exhibit greater MIC than essential oil which was used as a positive control. Additionally, fruit and root oils showed more efficacy against $E$. coli compared to gentamicin.
Zomorodian et al., (2018) uncovered the relationship between the antimicrobial activity and the presence of (E)-1-propenyl secbutyl disulfide and (Z)-1-propenyl sec-butyl disulfide as the major chemical compounds in the oil. In the same way, many studies have reported the link between antimicrobial activity of the essential oils with a high content of sulfur compounds (Iranshahi et al., 2008; Kavoosi and Rowshan, 2013; Divya et al., 2014). In this regard, Divya et al., (2014) demonstrated the morphological changes in fungal and bacterial cells tested with the $F$. assa-foetida essential oil using scanning electron microscopy. The morphological changes were like damaged bacterial membranes, irregular branching in fungal hyphae and sporulation inhibition and disruption of the cytoplasmic membrane, which result in leakage of ions and electrolytes. Additionally, $a$-pinene and 10-epi- $\gamma$-eudesmol were also reported as active terpenoids against the broad range of microorganisms (Rivas da Silva et al., 2012). Terpenoids are highly lipophilic in nature, so they target cell membranes and cause toxicity through cell membrane integrity disruption (Kovač et al., 2015).

\section{IMMUNOMODULATORY EFFECT}

Oüzek et al., (2017) elucidated the chemistry and immunomodulatory activity of the essential oil procured from the dried plant material of the Ferula iliensis Krasn. ex Korovin material by the hydro-distillation method with Clevenger apparatus (Z) and (E)-propenyl sec-butyl disulfide 23.4-45.0\% and $15.7-39.4 \%$, respectively were the major chemical constituents of the extracted plant essential oil. On the basis of the results of the experiments, it was concluded that the essential oil had the potential to stimulate $\left[\mathrm{Ca}^{2+}\right]$ ion mobilization and production of reactive oxygen species in the murine bone marrow phagocytes and human neutrophils. Furthermore, the effect of essential oil could be reversed by using capsazepine a TrpV1 channel antagonist, in a dose-dependent manner. This result indicated that TrpV1 channels were the target site for the essential oil component, which was likely to be (Z)-sec-butyl propenyl disulfide, aver by the molecular modeling method using a known TrpV1 agonist. Sadeghi et al., (2017) studies the effect of F. ovina essential oil on the immune system of Sesamia cretica Ledereer. The results proved that the essential oil had a visual effect on the S. cretica's immune system. Four main circulating hemocytes were identified in the fourth instar larvae which included oenocytoides, granulocytes (GRs), prohemocytes, and plasmatocytes. The 4th instar larvae were injected with $1 \mathrm{uL}$ of each concentration of $F$. ovina oils (1,000, 2,500 and 7,000 ppm). The total number of hemocyte and GR count enhanced with $1,000 \mathrm{ppm}$ concentration while decreased at 2,500 and 7,000 ppm concentration, dose-dependently. However, plasmatocyte numbers declined for all the treatment concentrations but more significantly with increased doses. However, the number of nodules and the phenol-oxidase activity was not affected by any tested essential oil concentration. Schepetkin et al., (2016) substantiated the effect of the Ferula akitschkensis B.Fedtsch. ex Koso-Pol. Essential oils on human neutrophils cells. Seed and 
stem oil possessed 4(10)-thujene, $\alpha$ - and $\beta$-pinene; 4-terpineol, eremophilene, 2-himalachene-7 $\beta$-ol myristicin and (E)-6,10dimethylundeca-5,9-dien-2-one as their primary components. The report analysis showed that the major component of umbels seeds namely $\beta$-pinene, 4(10)-thujene, $\gamma$-terpinene, (E)-6,10-dimethylundeca-5,9-dien-2-one, pichtosin, and (E)non-2-enal stimulated calcium mobilization in neutrophils cells. Especially, geranylacetone and isobornyl acetate showed great potential with $7.6 \pm 1.9$ and $6.4 \pm 1.7 \mu \mathrm{M} \mathrm{EC} \mathrm{E}_{50}$ value, respectively. Additionally, the treatment of neutrophil cells with the aforementioned components except (E)-2-nonenal, resulted in desensitization of the neutrophils due to fMLF ( $\mathrm{N}$-formyl-MetLeu-Phe) and IL-8 (interleukin-8) induced calcium ions flux and inhibition of $\mathrm{N}$-formyl-Met-Leu-Phe -induced chemotaxis in cells. The effect of these components on calcium ions flux in neutrophils could be inhibited by TRP channel blockers (transient receptor potential). A further study averred that geranylacetone was a TrpV1 agonist, and cause $\mathrm{Ca}^{2+}$ ions influx in TrpV1-transfected human embryonic kidney 293 cells (HEK293 cells); whereas myristicin was a TrpV1 antagonist, and inhibited fMLF and IL-8 mediated neutrophil $\left[\mathrm{Ca}^{+2}\right]_{\mathrm{i}}$ flux stimulation and abolished capsaicin (zostrix)induced $\mathrm{Ca}^{2+}$ ions influx in TrpV1-transfected human embryonic kidney 293 cells.

\section{ANTI-ACETYLCHOLINESTERASE, ANXIOLYTIC AND ANTISPASMODIC ACTIVITY}

Ahmadi et al., (2020) unearthed the anti-acetylcholinesterase activity of the essential oils of flowering tops, fruits, and roots of the Ferula aucheri Boiss. Piwczynski, Spalik, M. Panahi \& Puchalka with antimicrobial activity. The biochemistry of the oils was analyzed by GC-MS method; AChE inhibitory potential was assessed by Ellman's method with slight modification. The major portion of the chemical constituents of the essential oils belonged to the sesquiterpene hydrocarbon group (61.9\%). The essential oil of roots and fruits showed weak acetylcholinesterase (AChE) inhibitory potential with $239.69 \pm 3.5$ and $554.05 \pm 4.65 \mu \mathrm{g} / \mathrm{ml}$ half-maximal inhibitory concentration $\left(\mathrm{IC}_{50}\right)$ values, respectively whereas flowering tops essential oil presented moderate AChE inhibitory activity with $179.06 \pm 4.3 \mu \mathrm{g} / \mathrm{ml} \mathrm{IC}_{50}$ values. Znati et al., (2012) also inquired about the anti-acetylcholinesterase and antimicrobial properties of flower oil from Ferula lutea (Poir.) Maire. The chemical compounds of the essential oils were analyzed by GC-MS. The major portion of essential oil chemical constituents was covered with monoterpene hydrocarbon and sulfur-containing compounds. The result showed that the flower oil exhibits significant AChE inhibitory activity with a $\mathrm{IC}_{50}$ value of $70.25 \pm 5.41 \mu \mathrm{g} / \mathrm{ml}$. Deveci et al., (2018) examined the anticholinesterase activity along with antioxidant and anti-tyrosinase activity of $F$. elaeochytris Korovin essential oils. The result of GC-MS and GC-FID showed the presence of $21.3 \%$ of $\beta$-cubebene, $17.5 \%$ of caryophyllene oxide, and $14.9 \%$ of $\beta$-caryophyllene. The anticholinesterase activity was measured by Ellman's spectrophotometric method. The essential oil of $F$. elaeochytris exhibited the highest anticholinesterase and anti-tyrosinase activities. The anticholinesterase activity of the root's essential oil of Ferula lutea (Poir.) Maire. was also demonstrated by Ben et al., (2016). The constituents of hydrodistilled essential oils were analyzed by 13C-NMR, GC (FID) and GC-MS spectroscopy had a higher portion of monoterpene hydrocarbons viz. delta-car-3ene $(72.6 \%)$, alpha-pinene, myrcene, and alpha-phellandrene. The results indicated that this essential oil exhibited efficient antiacetylcholinesterase bioactivity with a $\mathrm{IC}_{50}$ value of $28.56 \pm$ $1.87 \mu \mathrm{g} / \mathrm{ml}$. The effects of Ferula heuffelii Griseb. ex Heuff. essential oil on contractions ( $\mathrm{KCl}$ and $\mathrm{ACh}$ induced or spontaneous) were examined by Pavlović et al., (2012). The essential oil has the potential to inhibit spontaneous contraction in rat ileum, dose-dependently. The essential oil exerted half of the atropine (positive control) effect at a $\mathrm{ED}_{50}$ value (median effective dose) of $86.64 \mu \mathrm{g} / \mathrm{ml}$. The acetylcholine mediated induction of contractions in ileum was inhibited at $75.00 \mu \mathrm{g} / \mathrm{ml}$ of the essential oil concentration, whereas at $250.00 \mu \mathrm{g} / \mathrm{ml}$ of essential oil concentration, the spasmodic effect of $\mathrm{KCl}(80 \mathrm{mM})$ was almost abolished. Sadraei et al., (2001) examined the effect of F. gummosa essential oil with other extracts (methanolic extracts, petrolic hydro-alcoholic, and etheric). F. gummosa essential oil (FGEO) inhibited the response to $\mathrm{KCl}(80 \mathrm{mM})$ at $10-360 \mu \mathrm{g} / \mathrm{ml}$ concentration whereas at $180 \mu \mathrm{g} / \mathrm{ml}$, concentration almost terminated the response to $\mathrm{KCl}$. Two components of essential oil namely $\alpha$ and $\beta$-pinene $(10 \mathrm{ng} / \mathrm{mL}-1.3 \mu \mathrm{g} / \mathrm{ml}$ and $2-138 \mathrm{ng} / \mathrm{ml}$, serially) inhibited the tonic contraction induced by $\mathrm{KCl}$ in a dosedependent manner. These two components also inhibited the $\mathrm{ACh}(80 \mathrm{mM})$ induced contraction. $\alpha$-Pinene $(180$ and $90 \mathrm{ng} / \mathrm{ml})$, $\beta$-pinene $(160,80,40$, and $20 \mathrm{ng} / \mathrm{ml})$ inhibited the acetylecholine induced contraction up to $45 \pm 9.7 \%$, and $95 \pm 1.7 \%$ to $79 \pm 7.7 \%$; $0.8 \pm 0.8 \%, 11 \pm 7.3,33 \pm 7.3$ and $95 \pm 2.3 \%$ to $84 \pm 78.9 \%$, sequentially $(p<0.05)$. The relaxant effect of oleo-gum-resin and seed oils of the F. assa-foetida on isolated rat's ileum was investigated by Bagheri et al., (2014a), Bagheri et al., (2014b), and Bagheri et al., (2014c). To reveal the relaxant effect of asafoetida resin and seed essential oil, the isolated ileum of rats treated with three doses, and isotonic contractions of the essential oil. The contractions of the specimen were induced by different doses $(0.3,0.2$, and $0.1 \%)$ of asafoetida and essential oil. The amplitude of contraction was recorded before and after exposure to acetylcholine (ACh) cumulative concentration. Results showed that asafoetida $(0.2 \%$ and $0.3 \%$ concentration) had an antispasmodic effect on acetylcholine-induced contraction. The essential oil also had effective antispasmodic activity against acetylcholine-induced contraction at concentrations $10^{-12}-10^{-2} \mathrm{M}$ of seed and asafoetida essential oils $(0.2 \%$ and $0.3 \%)$. These oils could cause a significant reduction in acetylcholine $\left(10^{-4} \mathrm{M}\right)$ induced contractions at (4.12) and 8 (2.4) concentration, $p=0.03$; up to $43 \%$ and $12 \%, p=0.02$, respectively. Batra et al., (2020) revealed the presence of triterpenoids with 32 other chemical components in the essential oil of Ferula sumbul Hook. roots. The essential oil $(50 \mu \mathrm{L} / \mathrm{kg})$ showed considerable anxiolytic activity in various tested models (light/dark, mirror chamber, elevated plus maze, 
$m$-CPP-induced and open-field anxiety). The results showed that the anxiolytic effect of the essential oil was mediated primarily through the benzodiazepines site on GABA receptors and through 5-HT receptors.

\section{GENOTOXIC AND ANTIGENOTOXIC PROPERTIES}

Ozkan et al., (2014) planned to evaluate the genotoxic and antigenotoxic activities of essential oil extracted from the leaves and flowers of Ferula orientalis L. grown in Erzurum. The chemical constituents of essential oil were characterized by the GC-MS method. $\alpha$-Cadinol (11.7\%), $\gamma$-cadinene, germacrene D-4-ol, epi- $\gamma$-muurolol ( $\alpha$-pinene 9.3\%, 11.9\%, 6.1\%) were recorded as the main chemical components in leaf $(10.45,8.1$, $6.8,5.9$, and $5.7 \%$, respectively) and flower $(9.3,11.9,6.1$, and $7.2 \%$, respectively) essential oils. According to their results, the chemical constituents were responsible for biological activities. Bacterial strains such as Salmonella typhimurium TA1537, S. typhimurium TA1535, and E. coli WP2 uvrA were used to evaluate the mutagenic activity, using the bacterial reverse mutation assay method. The study showed that tested leaf and flower essential oil did not have any mutagenic activity on $S$. typhimurium and E. coli strains at any used concentration. Nevertheless, the essential oil showed antimutagenic property against used mutagen, namely $\mathrm{N}$-methyl- $\mathrm{N}^{\prime}$-nitro- $\mathrm{N}$ nitrosoguanidine (MNNG), 9-aminoacridine (9-AA), and sodium azide $\left(\mathrm{NaN}_{3}\right)$. Further investigations showed the potential of the essential oils to reduce the effect of mutagens on bacterial strains which were as follows: $\mathrm{N}$-methyl- $\mathrm{N}^{\prime}$-nitro- $\mathrm{N}$ nitrosoguanidine on E. coli WP2 uvrA (23-52\%); 9aminoacridine on S. typhimurium TA1537 (40-68\%), sodium azide on S. typhimurium TA1535 (29-36\%).

\section{SCOLICIDAL ACTIVITY}

In a study, Tabari et al., (2019) revealed the effectiveness of $F$. gummosa's essential oil and its main components against Echinococcus granulosus protoscoleces. Results of GC/MS displayed $\beta$-pinene as an abundant chemical compound of the essential oil. Furthermore, the eosin staining method was used to measure mortality rate. The mean death rate of E. granulosus protoscoleces was recorded $100 \%$ at $50 \mu \mathrm{g} / \mathrm{ml}$ concentrations of the essential oil and 60 min exposure time. The essential oil of $F$. gummosa also showed a higher toxic effect on E. granulosus protoscoleces with $50 \% \mathrm{LC}_{50}$ values (lethal concentration) $17.18 \mu \mathrm{g} / \mathrm{ml}$. Additionally, $10 \mu \mathrm{g} / \mathrm{ml}$ concentrations of only $\beta$-pinene resulted in the death of tested microorganisms with more than $80 \%$ mortality rate. The collective toxic effect of $\beta$-pinene was efficiently greater than the compressive effect of all chemical compounds presented in the essential oils of $F$. gummosa. On the basis of $\mathrm{LC}_{50}$. values $(2.20 \mu \mathrm{g} / \mathrm{ml})$ of $\beta$-pinene was considered as the most potent scolicidal agent in this study. Kavoosi et al., (2013) demonstrated the scolicidal effectiveness of essential oil from F. assa-foetida with a plant. A sulfur-containing hydrocarbon (E)-sec-butyl propenyl disulfide, $62.7 \%$ ) was found to be the main component in the essential oil analyzed by the gas chromatography method. The results proved that $10 \mathrm{~min}$ exposure of $\mathrm{F}$. assafoetida essential oil with a concentration of $60 \mu \mathrm{g} / \mathrm{ml}$ or more could kill all Echinococcus granulosus protoscolices.

\section{TOXICITY}

Ye et al., (2011) studied the effect of chemical components separated from crude essential oil of $F$. sinkiangensis K.M.Shen, on acute toxicity in morphine-dependent animals. Two sulfur-containing compounds: 2-butyl cis-1-propenyl disulfide and 2-butyl trans-1-propenyl disulfide (SBD) were separated from the unrefined essential oil. To evaluate the effectiveness and naturally abstinent and naloxone-precipitated abstinent morphine-dependent models were applied and injected with 2-butyl trans-1-propenyl disulfide intraperitoneally. In addition, the antinociceptive effects, sedative effects, and acute toxicity of SBD were investigated by a writhing test, spontaneous activity test, and $\mathrm{LD}_{50}$ values, respectively. The result showed that SBD could be inhibited by the abstinent syndromes, and the 2butyl trans-1-propenyl disulfide had great sedative and antinociceptive effects as well. Tempark et al., (2016) indicated that topical administration of $F$. assa-foetida oleo-gum-resin essential oil could cause contact dermatitis in infants. This high content of disulfide-containing hydrocarbons in asafoetida oil might cause skin-irritating effects. These types of pro-inflammatory side effects could be diminished by the elimination or reduction of disulfide compounds from the essential oil.

\section{ANTIOXIDANT ACTIVITY}

Kavoosi et al., (2012) demonstrated the radical scavenging properties of $F$. assa-foetida. The essential oil was prepared by hydrodistillation contained (E)-sec-butyl propenyl disulfide and $\beta$-ocimene and pinene. The essential oil was subjected to different radical scavenging activity assays to evaluate the antioxidant potential. The report displayed that $F$. assa-foetida essential oils did not have any significant antioxidant activity. Pavlović et al., (2012) effectuated antioxidant potential of essential oil obtained from Ferula heuffelii Griseb. ex Heuff. underground parts. The main compounds of the essential oil were elemicin and myristicin with 35.4 and $20.6 \%$ total concentration. L-Ascorbic acid was used as a reference substance. The resulting investigation delineated that essential oils showed antiradical activity, concentration-dependently. The $\mathrm{SC}_{50}$ value was obtained at 22.43 and $3.80 \mu \mathrm{g} / \mathrm{ml}$ for tested essential oil and reference substance, respectively. Ahmadvand et al., (2014) revealed the antioxidant potential and chemical profile of $F$. assa-foetida leaf essential oil. Analysis of hydro-distilled leaves' essential oil revealed major chemical compounds namely eremophilene (31.28\%), $\delta$-cadinene, longiborneol, dehydro aromadendrene, and isoledene. Antioxidant activity was examined by using a 
$0.01-1,000 \mu \mathrm{g} / \mathrm{ml}$ essential oil concentration. Antioxidant activity analysis showed that the $\mathrm{IC}_{50}$ for DPPH (2,2-diphenyl-1picrylhydrazyl) free radicals was 2,375.66 $\pm 5.13 \mu \mathrm{g} / \mathrm{ml}$. Benchabane et al., (2012) analyzed the antioxidant potential of Ferula vesceritensis Coss. \& Durieu ex Trab. The chemical profile displayed viridiflorol (13.4\%) as a major constituent of oil and delta-cadinene, trans-farnesol, alpha-fenchyl acetate, aristolene, cadinol, and fonenol were also found in the essential oil. Antioxidant activity was accomplished by using a $100-1,000 \mathrm{mg} / \mathrm{L}$ oil concentration. Butylated hydroxytoluene (BHT) was used as a positive control with $100-1,000 \mathrm{mg} / \mathrm{L}$ concentrations. $F$. vesceritensis essential oil exhibited a reduction in DPPH free radical concentration but with lower efficacy compared to BHT. Znati et al., (2017) assessed different bioactivities of seed oil from Ferula tunetana Pomel ex Batt. including antioxidant bioactivity. Pinene $(\alpha / \beta)$ and $(\mathrm{Z})$ $\beta$-ocimene were characterized as the main component of the essential oil by gas chromatography and carbon-13 nuclear magnetic resonance methods. The essential oil displayed antioxidant activity with moderate efficiency. The $\mathrm{H}_{2} \mathrm{O}_{2}$ assay exhibited the highest activity with $78.2 \pm 2.98 \mu \mathrm{g} / \mathrm{ml} \mathrm{IC} \mathrm{I}_{50}$ value, while ABTS, DPPH, and superoxide anion assay radical scavenging assays showed $234.2 \pm 12.9,243.1 \pm 6.5$ and $89.2 \pm$ $3.82, \mu \mathrm{g} / \mathrm{mL} \mathrm{IC} \mathrm{I}_{50}$ values, sequentially. Amiri (2014) elucidated the antioxidant activity of methanolic extracts and essential oil of Ferula microcolea (Boiss.). $\alpha$-Pinene (27.3\%), $\beta$-pinene, nonanaldehyde, $\quad \beta$-caryophyllene, and 2 -isopropyl-5methylphenol were recognized as primary chemical constituents. The $\mathrm{IC}_{50}$ value for $\beta$-carotene-linoleic acid and $\mathrm{DPPH}$ were recorded at $55.2 \pm 0.4 \%$ and $253.1 \pm 2.2 \mu \mathrm{g} / \mathrm{ml}$, for essential oil content, respectively. Kose et al.,(2010) accomplished the antioxidant potential of Ferula lycia Boiss. essential oil. The bleaching of the carotene-linoleate and $\mathrm{DPPH}$ was used to examine the antioxidant activity of the essential oil. The essential oil $(0.4,1.0$ and $2.0 \mathrm{mg} / \mathrm{ml})$ showed $\beta$-carotene linoleic acid abilities $(5.69 \pm 2.04,16.16 \pm 0.52$, and $27.77 \pm 2.37 \mathrm{mg} / \mathrm{ml})$ and DPPH radical scavenging (11.05 \pm 0.50 , $1.91 \pm 0.43$ and $2.81 \pm 0.0 \mathrm{mg} / \mathrm{ml}$ ), respectively. Dadaşoğlu et al.,(2018) revealed the antibacterial and antioxidant activity of the essential oil of $F$. communis L. The essential oil showed antioxidant activity at $40.65 \%(0.1 \mathrm{ml})$ and $85.16 \%(0.2 \mathrm{ml})$ concentration for DPPH, ABTS assay, respectively. Jahani et al.,(2015) synthesized gelatin nano-capsules using $F$. assafoetida essential oil (FAO) and tested their potential to exhibit antibacterial and antioxidant activity. Essential oils containing gelatin nano-capsules were synthesized with Ferula oil at 2, 4, 6, and $8 \% \mathrm{w} / \mathrm{w}$ concentrations; $25 \% \mathrm{w} / \mathrm{w}$, glutaraldehyde (a crosslinker) and glycerol (plasticizer). Synthesized gelatin nanocapsules were evaluated by scanning electron microscopy. FAO incorporated gelatin nano-capsules exhibited excellent antioxidant and antibacterial at $8 \%$ of FAO concentration. Sharopov et al.,(2015) examined the antioxidant activity, along with the anti-inflammatory activity of essential oils of some aromatic plants including Ferula clematidifolia Koso-Pol., Ferula foetida (Bunge) Regel, etc. The results showed that both species had moderate antioxidant activity. Kavoosi and Rowshan (2013) also investigated the chemical profile and antioxidant potential of essential oil from $F$. assa-foetida oleo-gum-resin. F. assa-foetida resin (oleo-gum-resins, ORGs) was collected in three different times named as ORG1, ORG2, and OGR3 and subjected to hydro-distillation. The $\mathrm{IC}_{50}$ value for all listed scavenging methods were calculated as follows OGR1 $(0.017 \pm$ $0.0019,0.012 \pm 0.0020,0.035 \pm 0.0027$, and $0.022 \pm$ $0.0012 \mathrm{mg} / \mathrm{ml}) ;$ OGR2 $(0.031 \pm 0.0018,0.025 \pm 0.0023,0.047 \pm$ 0.0028 , and $0.033 \pm 0.0043 \mathrm{mg} / \mathrm{ml})$; OGR3 $(0.047 \pm 0.0028$, $0.035 \pm 0.0012,0.066 \pm 0.0042$, and $0.055 \pm 0.0038 \mathrm{mg} / \mathrm{ml}$ ) for RNS, ROS, TBARS, and $\mathrm{H}_{2} \mathrm{O}_{2}$ scavenging assay, respectively. Antioxidant activity of OGR1 (18.16 $\pm 1.2 \mathrm{mg})$, OGR2 (14.14 \pm $2.2 \mathrm{mg})$, and OGR3 (10.8 $\pm 2.5 \mathrm{mg})$ were observed at $\mathrm{mg}$ ascorbic acid/g of essential oil, respectively. Topdas et al.,(2020) revealed the antioxidant activity of Ferula orientalis L. essential oil containing $\alpha$-pinene, ortho-cymene, limonene, terpinolene, $\beta$-caryophyllene and isobornyl acetate as the major compounds. The antioxidant activity (in vitro) of the essential oil was analyzed. The report averred that the essential oil chemical group had significant antioxidant activity against the ABTS and DPPH free radicals. Sharopov et al.,(2019) revealed the antioxidant activities of hydrodistilled essential oil, extracted from the Ferula tadshikorum Pimenov. underground parts. Data analysis confirmed that the essential oil exerted lower antioxidant potential than the caffeic acid (positive control) with 17.8 and $8.2 \mathrm{mg} / \mathrm{ml}$ median inhibitory concentration $\left(\mathrm{IC}_{50}\right)$ for DPPH and ABTS, respectively.

\section{ANTIPROTOZOAL ACTIVITY}

Essid et al.,(2015) investigated the antileishmanial activity of essential oil from medicinal plants. This study included Ferula communis L. with 11 medicinal plants to identify the antileishmanial potential against Leishmania infantum and $L$. major promastigotes. The major components of F. communis were: $\beta$-caryophyllene (15.22\%), $\beta$-myrcene alpha-eudesmol, alpha-pinene, para-mentha-1, 5-dien-8-ol and $\gamma$-curcumene. Amphotericin B was applied as a form of positive control in the experimental setup. Data collected from the experiment setup showed that the essential oils had potent antileishmanial activity against $L$. infantum and $L$. major promastigotes at $\mathrm{IC}_{50}$ value $<1 \mu \mathrm{g} / \mathrm{ml}$. After result analysis, it was concluded that $L$. infantum promastigotes $\left(\mathrm{IC}_{50}\right.$ value $0.80 \pm 0.18 \mu \mathrm{g} / \mathrm{ml}$ ) were more sensitive to the essential oil and their constituents as compared to L. major $\left(\mathrm{IC}_{50}\right.$ value $\left.0.22 \pm 0.09 \mu \mathrm{g} / \mathrm{ml}\right)$. According to Essid et al., caryophyllene had high leishmanicidal activity against $L$. infantum and L. major $(1.06 \pm 0.37$ and $1.33 \pm 0.52 \mu \mathrm{g} / \mathrm{ml}$, respectively). Andrade et al.,(2016) effectuated the in vitro anti-leishmanial activity of different plants' essential oils including Ferula galbaniflua Boiss. \& Buhse. GC-MS analysis of the essential oil showed methyl pimar-8-en-18-oate (41.82\%) and diethyl phthalate $(13.09 \%)$ as main components. In vitro leishmaniacidal activity of essential oil was examined on Leishmania amazonensis promastigotes forms at $30-500 \mu \mathrm{g} / \mathrm{ml}$ oil concentrations. F. galbaniflua essential oil was more potent against $L$. amazonensisat at $95.70 \pm 1.82 \mu \mathrm{g} / \mathrm{ml}\left(\mathrm{IC}_{50} / 24 \mathrm{~h}\right)$. ElDeeb et al.,(2012) substantiated in vitro inhibitory effects of $F$. 
assa-foetida essential oil on Blastocystis species. The volatile oil of powdered assa-foetida was extracted by hydrodistillation and tested against the Blastocystis sp. subtype. Various concentrations such as $5,10,25,40$, and $50 \mathrm{mg} / \mathrm{ml}$ were used for 24,72 , and $144 \mathrm{~h}$. Metronidazole was used as the reference antiprotozoan drug including a 10, 100, and $500 \mu \mathrm{g} / \mathrm{ml}$ concentration. The results confirmed by microscopy described that extracted oil decreased the viability and counts of all the Blastocystis sp. The lowest and highest percentage inhibition values at which blastocysts showed no growth and multiplication were 16 and $40 \mathrm{mg} / \mathrm{ml}$, respectively. At the aforementioned concentration, the mean count was the same for the oil extract and the reference drug. Furthermore, recultivation of Blastocystis in oil-free medium did not display any growth even after 48,72 , and $144 \mathrm{~h}$ of cultivation.

\section{NEUROPROTECTIVE}

Topdas et al.,(2020) elucidated the neuroprotective potential of various types of extracts and essential oils of $F$. orientalis $\mathrm{L}$. Neuroprotective potential of the essential oil was investigated in cortex neuron cells by 2-(3,5-diphenyltetrazol-2-ium-2-yl)-4,5dimethyl-1,3-thiazole; bromide (MTT) assay. The essential oil concentrations ranging from $10^{-1}$ to $10^{-8}$ were used for the experiments. The cell groups treated with essential oil clearly exhibited the highest cell viability rates. The viability rates were $92.57 \pm 4.23,91.29 \pm 4.12$, and $83.60 \pm 3.98 \%$ at $10^{-2}, 10^{-3}$, and $10^{-4}$ of the oil concentration $(p>0.05)$, respectively. Moreover, the result clearly showed that at $10^{-2}$ concentration, the cell viability was at its peak, after this mentioned concentration of essential oil, the viability rates started to fall down slightly.

\section{ANTIGERMINATIVE ACTIVITY}

The in vitro antigerminative property of Ferula tunetana Pomel ex Batt. seed oil was demonstrated by Znati et al.,(2017). Four doses $(1.25,5,10$, and $20 \mathrm{mg})$ of the oil were prepared by diluting it in the emulsion in $5 \mathrm{ml}$ deionized $\mathrm{H}_{2} \mathrm{O}$. The essential oil exerted significant toxicity against Medicago sativa L., Triticum aestivum L. and Lactuca sativa Linn. Seven days of exposure to essential oil showed the maximum toxic effect with $0 \%$ germination. Furthermore, the germination of $M$. sativa, T. aestivum and $L$. sativa, seedlings were efficiently inhibited at a 20 and 10 (mg/ $5 \mathrm{ml}$ ) concentration. The authors suggested that $\alpha$-pinene (39.8\%) was responsible for the toxic effect.

\section{VASODILATORY OR VASORELAXANT ACTIVITY}

Esmaeili et al.,(2020) studied the role and significance of the $\mathrm{K}^{+}$channels in vasorelaxant and the effect of essential oil from asafoetida (AEO). The AEO obtained from F. assa-foetida oleoresin was subject to the vasodilation effect examination. This effect had two types (endothelium-independent and dependent). This research was designed to demonstrate whether intracellular $\mathrm{Ca}^{2+}$ release and $\mathrm{K}^{+}$channels had a contribution in the essential oilmediated vasodilation or not. For the experiments, isolated rats' thoracic aortas were denuded, and the concentration-response curve was plotted after induction of contraction by $\mathrm{KCl}$ $(60 \mathrm{mM})$ and addition of $0.625-80 \mu \mathrm{L} / \mathrm{L}$ of AEO in the medium. The vasodilatory effect of the essential oil was studied by the addition of essential oil in the medium before and after the addition of phenylephrine and potassium channel blocking chemicals viz. barium chloride $\left(\mathrm{BaCl}_{2}\right)$, glibenclamide (GL) and 4-aminopyridine (4A). AEO displayed a relaxant effect on the precontracted rings, concentration-dependently at a $23 \mu \mathrm{L} / \mathrm{L} \mathrm{IC}_{50}$ value. Furthermore, it was observed that $\mathrm{K}^{+}$channel blockers significantly abolished the AEO mediated vasodilatory effect, if it was added before the addition of $\mathrm{KCl}$ to the ring medium. In contrast to potassium channel blockers, the tension was significantly decreased with the addition of the AEO before or after phenylephrine addition. The result interpreted that the inhibition of $\mathrm{Ca}^{+2}$ channels and the activation of smooth muscle membrane $\mathrm{K}^{+}$channels were responsible for the vasodilatory effect of the essential oil on the denude $\gamma$-endothelium aortic ring. Esmaeili et al.,(2017) investigated the vasodilatory activity of AEO using rat aorta ring as a living system. The contribution of $\mathrm{Ca}^{+2}$ channel, prostacyclin and $\mathrm{NO}$ (nitric oxide) in the vasodilation process were additional. In an experiment, thoracic aorta rings were stretched in an organ bath apparatus, after that the rings precontracted using $80 \mathrm{mM}$ of $\mathrm{KCl}$ with or without the $\mathrm{AEO}$ portion. To reveal the role of nitric oxide and prostacyclin in the AEO vasodilatory effect, indomethacin (blocker of cyclooxygenase) and L-NAME (NO synthase blocker) were used. The AEO effect on the influx of $\mathrm{Ca}^{+2}$ ions were also evaluated. Data showed that the essential oil exerted significant effects on the aorta rings' vasodilation; the $\mathrm{IC}_{50}$ values for denuded and intact endothelium cells were 19.2 and $1.6 \mu \mathrm{L} / \mathrm{L}$, sequentially. The AEO mediated vasodilatory could reduce by L-NAME or indomethacin but could not be abolished. On the basis of the result, it was concluded that the AEO had an effective vasodilation activity, which could be endothelium-dependent or independent. AEO also decreased the influx of $\mathrm{Ca}^{+2}$ ions from the calcium channels of the plasma membrane into the cell.

\section{ANTIEPILEPTIC OR ANTICONVULSANT AND HYPOTENSIVE EFFECT}

Sayah et al.,(2001) used the fruit essential oil of the F. gummosa to evaluate antiepileptic activity. The result showed that the essential oil had no measurable effect on maximal electroshock-induced seizures, but it can reduce the effect of pentylenetetrazole-induced tonic seizures in mice. GC analyses of the essential oil presented pinene $(\beta: 50.1 \% ; \alpha: 18.3 \%)$, delta-3-carene $(6.7 \%)$, origanene (3.3\%), and 4(10)-thujene (3.1\%) as the main components. It was also suggested that toxic and anticonvulsant effects of the essential oil might be related to the compounds $\alpha$-thujene and $\beta$-pinene. Ghanbari et al.,(2012) aimed to reveal the chronic and acute effects of Ferula persica Willd. on hypertensive rats' blood pressure. Their study presented that the hypotensive effect might 
be due to the presence of safranal, a component of the F. persica EO. Furthermore, it was found that $F$. persica's essential oil might exert a hypotensive effect by the induction of nitrous oxide release and muscarinic receptors targeting in rats.

\section{HYPOGLYCEMIC AND HYPOLIPIDEMIC EFFECT}

Heydari-Majd et al.,(2019) performed the synthesis of F. gummosa essential oil or barije essential oil (BEO) incorporated zein nanofibre, subjected to $\alpha$-amylase and $\alpha$-glucosidase inhibitory action. GC/MS analysis of BEO revealed the presence of alphapinene, guai-1 (10)-en-11-ol, champacol and $\beta$-myrcene as the major components of the oil. Morphological analysis of prepared zein nanofibers done by SEM and FT-IR showed that the essential oil components were successfully entangled in the ribbon structured zein fibers with $\sim 95 \%$ encapsulation efficiency. BEOloaded $(1-4 \% \mathrm{w} / \mathrm{w})$ zein nano-fibers exhibited $\alpha$-amylase $\left(\mathrm{IC}_{50}\right.$ : $1.09 \pm 0.02$ to $1.64 \pm 0.01 \mathrm{mg} / \mathrm{ml})$ and $\alpha$-glucosidase $\left(\mathrm{IC}_{50}: 0.78 \pm\right.$ 0.01 to $1.25 \pm 0.03 \mathrm{mg} / \mathrm{ml}$ ) inhibition activity. The model-fitting results showed that BEO-loaded zein nano-fibers could be a delivery vehicle for diabetes control. Karimlar et al.,(2019) exposed the hypoglycemic and hypolipidemic effects of three medicinal plants' essential oils including $F$. gummosa on streptozotocin-induced diabetic rats. For the experimental setup the streptozotocin-induced ( $45 \mathrm{mg} / \mathrm{kg}$ doses, intraperitoneally) male wistar rats were used and treated with the essential oil (200 mg/kg/day). After 30 days, rats' lipid profiles and serum glucose were assessed. Data were examined by the Tukey test and one-way ANOVA test. The value of HDL-C, LDL-C, cholesterol, triglyceride, and glucose in F. gummosa essential oil treated rats' blood were recorded as $42.07 \pm 9.68,29.59 \pm 3.76$, $91.02 \pm 11.95,105.18 \pm 12.13$, and $429.91 \pm 46.14 \mu \mathrm{M}$, respectively. The F. gummosa essential oil significantly reduced low-density lipoprotein cholesterol and triglycerides in diabetic rats; even though the essential oil tested group did not display any significant difference in glucose level from the diabetic group. Yarizade et al.,(2017) studied the antidiabetic activity of $F$. assafoetida. In this study, it was observed that $F$. assa-fetida showed its antidiabetic activity by inhibiting $a$-glucosidase and DPP-IV (Dipeptidyl peptidase- IV).

\section{ANTINOCICEPTIVE AND HYPERALGESIA EFFECT}

In a study, Radulović et al.,(2013) reported hyperalgesia induction in mice with a chemical compound isolated from F. ovina (Boiss.) Boiss. The chemical profile of aerial parts of the essential oil of the F. ovina revealed the presence of a rare aromatic ester of monoterpenic alcohol named bornyl 4-methoxybenzoate, and its structure was evaluated by X-ray crystallographic analysis. The analgesic effect (the hot plate and tail immersion tests) and antinociceptive activity (abdominal writhings test) of the new compound with other oil constituents were elucidated. To determine the effect of essential oil and bornyl 4- methoxybenzoate, an experiment was performed using male $\mathrm{BALB} / \mathrm{c}$ mice as laboratory models. The results showed that bornyl 4-methoxybenzoate induced hyperalgesia in mice which is revealed by a hot plate test. The transient receptor channels (TrpV3) could have a target for tested substances and is a possible reason for hyperalgesia. The oil was found to have exerted a modest central and significant peripheral analgesic effect. The oil rendered a significant antinociceptive activity, dose-dependently, and abolished acetic acid-induced abdominal writhings. The number of writhings was reduced by up to $92 \%$ at $200 \mathrm{mg} / \mathrm{kg}$ essential oil concentration and up to $83 \%$ at $200 \mathrm{mg} / \mathrm{kg}$ bornyl 4methoxybenzoate concentration in treated mice was observed. Some of the major chemical constituents such as myrcene, limonene, and $\alpha$-pinene were ascribed to possess certain analgesic potential. The result showed that essential oil and bornyl 4-methoxybenzoate could have caused inhibition of prostaglandin synthesis. Bagheri et al.,(2016) studied the antinociceptive potential of $F$. assa-foetida seed essential oil in mice. To evaluate the antinociceptive effect of the essential oil (2.5, 5 and $10 \mathrm{mg} / \mathrm{kg}$ ), acetic acid-induced writhing and a hot plate test were used and for the control group morphine sulfate $(8 \mathrm{mg} / \mathrm{kg})$ or sodium diclofenac $(30 \mathrm{mg} / \mathrm{kg})$ were applied. Hot plate testing results showed that the percentage of the MPE (maximum possible effect) was higher for all used concentrations of the essential oil than morphine sulfate and sodium diclofenac. The writhes numbers were significantly less in the essential oil treated mice as compared to the control group. This research findings indicated that the essential oil reduces acetic acid-induced writhes numbers dose-dependently and presented a potent antinociceptive effect on acute/chronic pain in mice. The analgesic effect of the essential oil is thought to be either due to its action on acetic acidsensitive visceral receptors or inhibition of synthesis and action of prostaglandins and also cyclooxygenase and/or lipoxygenase in the arachidonic acid cascade at the peripheral route.

\section{ANTICANCER AND ANTITUMOR ACTIVITY}

Hosseinzadeh et al.,(2020a), Hosseinzadeh et al.,(2020b) performed the synthesis of gold nanoparticles using essential oil obtained from the gum of $F$. persica Willd. and evaluated their in vitro anticancer effects. Phytochemistry profiles were effectuated by the GC- MS method and displayed 27 constituents such as $\alpha$-pinene (27.1\%), (Z)-sec-butyl propenyl disulfide $(20.2 \%)$ and $\beta$-pinene $(10.6 \%)$ as the major component. The gold nanoparticles (Au NPs), which were characterized by ultraviolet-visible spectroscopy showed absorption at $530 \mathrm{~nm}$. The shape (spherical) and size $(37.05-78.6 \mathrm{~nm})$ of $\mathrm{Au}$ NPs were confirmed by TEM image. The presence of reducing and capping essential oil compounds on the gold ions and metal crystal structure was revealed by the FTIR spectrum and XRD pattern, respectively. The apoptosis and cytotoxicity assessment were performed by MTT [3-(4,5-dimethylthiazol-2-yl)-2,5diphenyl tetrazolium bromide] assay and $\mathrm{AO} / \mathrm{EB}$ (acridine orange/ethidium bromide) staining using non-cancerous (Vero cells) cells and cancerous (Murine colon carcinoma CT26) cells. The result showed that the cytotoxicity effect of Au NPs was dose- 
dependent and exhibited cytotoxicity against Vero cell and murine colon carcinoma CT26 lines with $\mathrm{IC}_{50}$ values 0.0024 and $0.0307 \mathrm{mg} / \mathrm{ml}$, respectively. Further, AuNPs inhibited colony formation in the aforementioned cells and induced apoptosis. The effect of AuNPs was reported more intensively against CT26 cells. The result clearly indicated the cytotoxic, apoptotic, and antiproliferative potential of the synthesized Au NPs. Elghwaji et al.,(2017) aimed to study the antitumor potentiality of the Ferula tingitana L. of essential oil. The essential oils were obtained from the hydrodistillation of flower and leaves possessing sesquiterpenes and oxygenated sesquiterpenes as their major chemical components, respectively. Cytotoxicity against human tumor cells viz. hormone-responsive breast (MCF7) cells, cervical (HeLa) cells and liver carcinoma (HePG2) cells were performed by sulforhodamine B (SRB) method using different doses of the essential oil $(0.0-50.0 \mu \mathrm{g} / \mathrm{ml})$. The $\mathrm{IC}_{50} \%$ value for in vitro cytotoxicity of flower and leaf derived essential oils against liver carcinoma (HEPG2), cervical (HELA), and breast (MCF7) cell lines (two different) were 4.4, 4.2; 8.6, 10.9 and $6.9,4.8 \mu \mathrm{g} / \mathrm{ml}$, respectively. Dithiolane found in high concentrations in F. assa-foetida essential oil; this compound exhibited antiproliferative activity in two human liver carcinoma cell lines (SK-Hepland HepG2), dose-dependently. Two signaling molecules: NF-kB and TGF- $\beta$ altered after the use of bioactive compounds of $F$. assa-foetida; moreover, an increase in caspase- 3 and TNF- $\alpha$ expression was observed and caused induction of apoptosis (Verma et al., 2019).

\section{CYTOTOXIC ACTIVITY}

The chemical profile and bioactivity of essential oil from underground parts of the Ferula tadshikorum Pimenov. were investigated (Sharopov et al., 2019). The chemical profile analysis revealed sulfur-containing hydrocarbon as a major component. The assessment of the cytotoxic effect of the essential oil was done on CEM/ADR5000 and CCRF-CEM cancer cell lines by using an MTT assay. Data displayed $\mathrm{IC}_{50}$ values were $142.5 \mu \mathrm{g} / \mathrm{ml}$ and $21.6 \mu \mathrm{g} / \mathrm{ml}$ for CEM/ADR5000 and CCRF-CEM cell lines, respectively. The essential oil shows a reduced cytotoxicity effect on CEM/ADR5000, due to the presence of substrates P-glycoprotein (p-gp) and overexpression of ATP-binding cassette transporter $\mathrm{p}$-gp, and it rapidly pumped all the active molecules of essential oil out of the cells. Ben et al.,(2016) elucidated the cytotoxic effect of the root oil obtained from the Ferula lutea (Poir.) Maire. The chemical profile of the oil was investigated by GC-MS/FID and 13C-NMR spectroscopy revealed the major component viz. delta-3-carene $(\sim 73 \%)$. The cytotoxic effect of the essential oil was carried out using the MTT method on human colon cell lines (HCT-116 and HT-29 cells). For the testing, Paclitaxel was added as a positive control. The result of MTT assay delineated that the hydrodistilled F. lutea roots' essential oil has a moderate cytotoxic effect on HT-29 and HCT-116 cells (Khajeh et al., 2005). The IC $_{50}$ values were $26.39 \pm 3.98 \mu \mathrm{g} / \mathrm{ml}$ and $81.00 \pm 12.81 \mu \mathrm{g} / \mathrm{ml}$ for HT-29 and HCT-116, respectively. The result showed that HCT-116 cells were extra sensitive to the isolated essential oil compared to HT-29 cells. The cytotoxicity of gum essential oil from F. persica Willd. on Vero cell lines and murine colon carcinoma (CT26) was demonstrated by MTT assay (Hosseinzadeh et al., 2020a; Hosseinzadeh et al., 2020b). The primary component of the essential oil was alpha-pinene (27\%), (Z)-sec-butyl propenyl disulfide (20\%), $\beta$-pinene (11\%), transdihydroagarofuran (6\%), allo-aromadendrene (5\%), (Z)$\beta$-ocimene $(4.5 \%)$ and $\alpha$-caryophyllene $(3 \%)$. The viability was decreased in the Vero cell $\left(0.125 \times 10^{-9}\right.$ to $\left.80 \mu \mathrm{L} / \mathrm{ml}\right)$ and CT26 cell line $\left(0.125 \times 10^{-9}\right.$ to $\left.20 \mu \mathrm{L} / \mathrm{ml}\right)$ significantly with all different concentrations of the essential oil treatment, dose-dependently. The $\mathrm{IC}_{50}$ value for the CT26 cell line $(0.3247 \mu \mathrm{L} / \mathrm{ml})$ was relatively greater than Vero cells $(0.0010 \mu \mathrm{L} / \mathrm{ml})$. The essential oil treatment exhibited valuable inhibition of colony formation in Vero cells and CT26 compared to the control. Moreover, some measurable changes such as morphological changes, the monolayer of the cells with areas devoid of cells, nucleus condensation, blebbing of the cell membrane, and apoptotic body formation were observed in fluorescence microscope by AO/EB staining. Bagheri et al.,(2017a) studied the cytotoxic effect of ferulic acid and essential oil obtained from oleogum resin of F. assa-foetida on 4T1 breast cancer cells. Data analysis enlightened the fact that the incubation of breast cancer $4 \mathrm{~T} 1$ cells with the essential oil at the concentration ranging from 1 to $1,000 \mu \mathrm{g} /$ $\mathrm{ml}$ for $24 \mathrm{~h}$ did not show any significant cytotoxicity. Additionally, the viability of cancer cells started to gradually decrease after 48 and $72 \mathrm{~h}$ of the incubation period. Nevertheless, a $10 \%$ cell viability rate was remarked even after the incubation with the highest concentration $(1,000 \mu \mathrm{g} / \mathrm{ml})$ of the essential oil for $72 \mathrm{~h}$. On the basis of the result, it could be concluded that the cytotoxic effect of the essential oil was time and concentration-dependent. Nguir et al.,(2016) used the Hela cervix cell and A549 human lung epithelial carcinoma cell lines to assess the cytotoxicity of $F$. communis L. essential oil (flowers, roots, leaves, and stems). The MTT test method was used with slight modifications.

For the activity assessment, the cell lines were treated with the essential oil at different concentrations. It was observed that activity was increased in both cell lines with a higher essential oil concentration, but at $500 \mu \mathrm{g} / \mathrm{ml}$ concentration significant activities were observed in both cell lines. Moreover, the Hela cells were reported to be more sensitive than A549 cells and displayed $79.05 \%$ and $77.52 \%$ inhibition at 500 and $250 \mu \mathrm{g} / \mathrm{ml}$ concentration of stem essential oil, respectively; flower essential oil showed 74.89\% inhibition. Abbaszadegan et al.,(2015) demonstrated the cytotoxicity of Ferula gummosa essential oil against L929 mouse fibroblasts using a colorimetric, MTT assay, and the Sigma-Aldrich method. Chlorhexidine (CHX: 0.2\%) and sodium hypochlorite ( $\mathrm{NaOCl}$ : $5 \%$ ) solutions were used as a control. The cytocompatibility of the essential oil was estimated on L929 fibroblast cells in comparison to the control. The chemical profile analysis of the essential oil displayed the presence of 27 chemical constituents. $\beta$-Pinene $(51.83 \%)$ was the main component in the essential oil. In the experiment, culture medium and $\mathrm{H}_{2} \mathrm{O}_{2}(35 \%)$ were used as the negative and positive controls, respectively. The cytotoxicity assessment showed that the full concentration $(50 \mu \mathrm{L} /$ $\mathrm{ml}$ ) of the essential oil had the ability to keep the mean cell viability of L929 mouse fibroblast cells at about $88 \%$. There was no measurable difference in the mean viability, of the negative control group $\left(\mathrm{H}_{2} \mathrm{O}_{2}\right)$ and in $\mathrm{NaOCl}(5 \%)$ and $\mathrm{CHX}(0.2 \%)$ treated cells. Additionally, no significant variation between the 
cytotoxic effect of the essential oil and $\mathrm{CHX}$ or $\mathrm{NaOCl}$ was observed. Kavoosi and Purfard (2013) considered phenolic monoterpenes as a target site for essential oils to show their cytotoxic effect which was the cytoplasmic and mitochondrial membrane. The oil molecules pass through the cytoplasmic membrane and increase permeabilization, and ions leakage (especially, potassium and calcium) from membranes reduces membrane electric potential, ATP, amino acids, proteins synthesis, and cell death.

\section{MISCELLANEOUS ACTIVITY}

Rashidi et al.,(2014) demonstrated the galbanum prophylactic effect on caffeine teratogenic effects. For the experiment, four groups of pregnant rats were selected: one group (control) was injected with saline, two groups with galbanum $(200 \mathrm{mg} / \mathrm{kg})$, caffeine $(80 \mathrm{mg} / \mathrm{kg})$, and the remaining group with both compounds (galbanum + caffeine), intraperitoneally for 9-11 days of gestation. To obtain the data, fetuses (20th day of gestation) were collected and stained using Alizarin red-Alcian blue method. The report established that galbanum decreased caffeine-induced cleft palate incidence by $8.3 \%$ in the galbanum group as compared to the caffeine group (33.3\%). Kavoosi et al.,(2013) tried to develop F. assa-foetida essential oil incorporated wound dressing film with potent antibacterial and antioxidant properties. The film was prepared with $10 \% \mathrm{w} / \mathrm{v}$ gelatin solutions containing different concentrations of the essential oil. The result analysis displayed that the entraption of essential oil into gelatin films showed a valuable reduction in tensile strength swelling, elastic modulus and vapor penetrability; enhancement in solubility and resistance. However, essential oil incorporated gelatin film displayed appreciable antioxidant and antimicrobial activities compared to gelatin film without essential oil. In a study, Esmaeili et al.,(2018) investigated the effect of the essential oil on a myocardial ischemic-reperfusion injury obtained from $F$. assafoetida (AEO). Three concentrations of AEO (0.50, 0.25 and $0.125 \mu \mathrm{L} / \mathrm{g}$ heart) were used. The results of the analysis showed that the AEO treated group exhibited severe myocardial dysfunction with a significant increase in left ventricular enddiastolic pressure and a reduction in left ventricular developed pressure as compared to the control group. The markers of myocardial injury (lactate dehydrogenase and creatine kinase) were also significantly active in the treated group compared to the control. Moreover, the essential oil exerted an effect on perfusion in isolated rat hearts at $0.5 \mu \mathrm{L} / \mathrm{g}$ heart concentration, but not below these concentrations.

\section{CONCLUSION AND FUTURE PERSPECTIVES}

The trend of natural products in the medical and other fields is growing and replacing the use of chemically synthesized drugs. Therefore, numerous scientific investigations have been conducted over a few decades. On the basis of the literature, the genus Ferula is a well-known genus of the Apiaceae family. It is widely used as an aroma spice in different foods all over the world. To date, a large number of biologically active components have been separated from the essential oils of Ferula which have shown the many different activities such as antimicrobial, insecticidal, antioxidant, antigerminative, cytotoxic, antitumor, antidiabetic activities, etc. All these activities have been discussed in this review. A large number of reports have been conducted on the variability in the chemical composition (quality and quantity) of essential oil extracted from the members of the genus Ferula. In these reports, it has clearly been stated that environmental factors, genetic factors, geographical area, and collection time have a great effect on essential oil composition. Ferula essential oil showed great anti-cancerous activity against various tested cancer cell lines. After a literature survey on the antimicrobial and insecticidal potential of this genus, it can be concluded that the essential oils are effective drug candidates for developing natural or semi-synthetic derivatives against drug-resistant microbes and insects and protozoan (Leishmania). Along with all the positive points, there are some negative points associated with essential oils derived from this genus which should be considered. Some species of Ferula show toxicity in humans and animals. Further, research is therefore needed in order to develop a befitting standard of the safe use of essential oils. The pharmaceutical potential of the essential oil of the Ferula species is still not completely understood. The revealed bioactivities are reported in vitro, therefore their practical application should be focused on and detailed studies are also needed to find new chemical constituents in the genus.

\section{AUTHOR CONTRIBUTIONS}

MM and PS conceived the idea of the review, provided the general concept and inputs for each specific section, and drafted part of the manuscript. PS and MM wrote the review after collecting literature. MM edited, compiled, and finalized the draft. Finally, both the authors read and approved it for publication.

\section{FUNDING}

This study was supported by the Startup Research Grant (UGC Faculty Research Promotion Scheme; FRPS) and sustained by Mohanlal Sukhadia University, Udaipur, Rajasthan, India.

\section{ACKNOWLEDGMENTS}

The author, MM is thankful to Mohanlal Sukhadia University, Udaipur for providing the necessary facilities during the course of the study. 


\section{REFERENCES}

Abbasnia, V. S., and Aeinfar, H. (2016). Anxiolytic and hypnotic effect of Ferula assafoetida aqueous extract in mice. Int. J. Pharm. Technol. 8, 15974-15979.

Abbaszadegan, A., Gholami, A., Mirhadi, H., Saliminasab, M., Kazemi, A., and Moein, M. R. (2015). Antimicrobial and cytotoxic activity of Ferula gummosa plant essential oil compared to $\mathrm{NaOCl}$ and $\mathrm{CHX}$ : a preliminary in vitro study. Restor. Dent. Endod. 40 (1), 50-57. doi:10.5395/rde.2015.40.1.50

Afshar, F. F., Saffarian, P., Hosseini, H. M., Sattarian, F., Amin, M., and Fooladi, A. A. I. (2016). Antimicrobial effects of Ferula gummosa Boiss gum against extended-spectrum $\beta$-lactamase producing Acinetobacter clinical isolates. Iran. J. Microbiol. 8 (4), 263. doi:10.2174/1574891X13666180426163427

Ahmadi, K. S., Hadjiakhoondi, A., Delnavazi, M. R., Tofighi, Z., Ajani, Y., and Kiashi, F. (2020). Chemical composition and biological activity of Ferula aucheri essential oil. Res. J. Pharmacogn. 7 (2), 21-31. doi:10.22127/RJP. 2020.210354.1537

Ahmadvand, H., Amiri, H., Dehghani Elmi, Z., and Bagheri, S. (2014). Chemical composition and antioxidant properties of Ferula-assa-foetida leaves essential oil. Iran. J. Pharm. Therapeut. 12 (2), 52-57. http://ijpt.iums.ac.ir/article-1-262-en.html.

Akhzari, D., and Saadatfar, A. (2019). Growth, phytoremediation potency and essential oil component of Ferula haussknechtii H. Wolff ex Rech. f. grown under lead stress conditions. J. Rangel. Sci. 9 (4), 392-401. doi:10.3390/ biom10040592

Al-Ja'fari, A. H., Vila, R., Freixa, B., Tomi, F., Casanova, J., Costa, J., et al. (2011). Composition and antifungal activity of the essential oil from the rhizome and roots of Ferula hermonis. Phytochemistry. 72 (11-12), 1406-1413. doi:10.1016/j. phytochem.2011.04.013

Alipour, Z., Taheri, P., and Samadi, N. (2015). Chemical composition and antibacterial activity of the essential oils from flower, leaf and stem of Ferula cupularis growing wild in Iran. Pharm. Biol. 53 (4), 483-487. doi:10. 3109/13880209.2014.924149

Alizadeh, M. N., Rashidi, M., Muhammadnejad, A., Zanjani, T. M., and Ziai, S. A. (2018). Antitumor effects of umbelliprenin in a mouse model of colorectal cancer. Iran J. Pharm. Res. IJPR. 17 (3), 976-985. doi:10.3390/molecules 24234278

Amalraj, A., and Gopi, S. (2017). Biological activities and medicinal properties of Asafoetida: a review. J. Tradit. Complement. Med. 7 (3), 347-359. doi:10.1016/j. jtcme.2016.11.004

Amin, A., Tuenter, E., Cos, P., Maes, L., Exarchou, V., Apers, S., et al. (2016). Antiprotozoal and antiglycation activities of sesquiterpene coumarins from Ferula narthex exudate. Molecules. 21 (10), 1287. doi:10.3390/molecules 21101287

Amiri, H. (2014). Chemical composition and antioxidant activity of essential oil and methanolic extracts of Ferula microcolea Boiss (Apiaceae). Int. J. Food Prop. 17 (4), 722-730. doi:10.1080/10942912.2012.665403

Andrade, M. A., Azevedo, C., Motta, F. N., Santos, M. L., Silva, C. L., Santana, J. M., et al. (2016). Essential oils: In vitro activity against Leishmania amazonensis, cytotoxicity and chemical composition. BMC Compl. Alternative Med. 16 (1), 444. doi:10.1186/s12906-016-1401-9

Arjmand, Z., and Dastan, D. (2020). Chemical characterization and biological activity of essential oils from the aerial part and root of Ferula haussknechtii. Flavour Fragr. J. 35 (1), 114-123. doi:10.1002/ffj.3544

Asemani, Y., Azadmehr, A., Hajiaghaee, R., and Amirghofran, Z. (2018). Anticancer potential of Ferula hezarlalehzarica Y. Ajani fraction in Raji lymphoma cell line: induction of apoptosis, cell cycle arrest, and changes in mitochondrial membrane potential. Daru. 26 (2), 143-154. doi:10.1007/ s40199-018-0219-z

Asilbekova, D. T., Ozek, G., Ozek, T., Bobakulov, K. M., Baser, K. H. C., and Sagdullaev, S. S. (2019). Essential oil and lipids from leaves of Ferula kuhistanica. Chem. Nat. Compd. 55 (6), 993-998. doi:10.1007/s10600-01902877-3

Azarnivand, H., Alikhah-Asl, M., Jafari, M., Arzani, H., Amin, G., and Mousavi, S. S. (2011). Comparison of essential oils from Ferula ovina (Boiss.) aerial parts in fresh and dry stages. J. Essent. Oil-Bear. Plants. 14 (2), 250-254. doi:10.1080/ 0972060X.2011.10643929

Aziz, Z. A., Ahmad, A., Setapar, S. H. M., Karakucuk, A., Azim, M. M., Lokhat, D., et al. (2018). Essential oils: extraction techniques, pharmaceutical and therapeutic potential-a review. Curr. Drug Metabol. 19 (13), 1100-1110. doi:10.2174/1389200219666180723144850
Baccari, W., Znati, M., Zardi-Bergaoui, A., Chaieb, I., Flamini, G., Ascrizzi, R., et al. (2020). Composition and insecticide potential against Tribolium castaneum of the fractionated essential oil from the flowers of the Tunisian endemic plant Ferula tunetana Pomel ex Batt. Ind. Crop. Prod. 143, 111888. doi:10.1016/j. indcrop.2019.111888

Bagheri, M., and Rahimi, M. (2014). Effect of Ferula assafoetida essential oil in controlling the black bean aphid. Int. J. Biosci. 5 (12), 350-356. doi:10.12692/ijb/ 5.12.350-356

Bagheri, S. M., Asl, A. A., Shams, A., Mirghanizadeh-Bafghi, S. A., and Hafizibarjin, Z. (2017a). Evaluation of cytotoxicity effects of oleo-gum-resin and its essential oil of Ferula assa-foetida and ferulic acid on 4T1 breast cancer cells. Indian J. Med. Paediatr. Oncol. 38 (2), 116. doi:10.4103/ijmpo.ijmpo_60_16

Bagheri, S. M., Dashti-R, M. H., and Morshedi, A. (2014a). Antinociceptive effect of Ferula assa-foetida oleo-gum-resin in mice. Res. Pharm. Sci. 9 (3), 207.

Bagheri, S. M., Rezvani, M. E., Vahidi, A. R., and Esmaili, M. (2014b). Anticonvulsant effect of Ferula assa-foetida oleo gum resin on chemical and amygdala-kindled rats. N. Am. J. Med. Sci. 6 (8), 408-412. doi:10.4103/19472714.139296

Bagheri, S. M., Hejazian, S. H., and Dashti-R, M. H. (2014c). The relaxant effect of seed fs essential oil and oleo-gum-resin of Ferula assa-foetida on isolated rat's ileum. Ann. Med. Health Sci. Res. 4 (2), 238-241. doi:10.4103/2141-9248. 129050

Bagheri, S. M., Hedesh, S. T., Mirjalili, A., and Dashti-R, M. H. (2016). Evaluation of anti-inflammatory and some possible mechanisms of antinociceptive effect of Ferula assa foetida oleo gum resin. J. Evid. Based Complem. Altern. Med. 21 (4), 271-276. doi:10.1177/2156587215605903

Bagheri, S. M., Sahebkar, A., Gohari, A. R., Saeidnia, S., Malmir, M., and Iranshahi, M. (2010). Evaluation of cytotoxicity and anticonvulsant activity of some Iranian medicinal Ferula species. Pharm. Biol. 48 (3), 242-246. doi:10.3109/ 13880200903081796

Bagheri, S. M., Mohamadsadeghi, H., and Hejazian, E. S. (2017b). Antinociceptive effect of seed's essential oil of Ferula assa-foetida in mice. Int. J. Clin. Exp. Pathol. 4 (1), 34-37. doi:10.4103/2141-9248.129050

Bagheri, S. M., Yadegari, M., Zare-Mohazabiye, F., Momeni-Asl, H., Mirjalili, A., Anvari, M., et al. (2018). Effect of Ferula assa foetida oleo-gum-resin on gastric ulcer in indomethacin-ulcerated rats. Int. J. Curr. Res. Sci. Med. 4 (1), 42-46. doi:10.4103/jcrsm.jcrsm_48_17

Bahrami, R., Kocheili, F., and Ziaee, M. (2016). Fumigant toxicity and persistence of essential oils from asafetida, geranium, and walnut on adults of Rhyzopertha dominica (Col.: bostrichidae). Toxin Rev. 35 (3-4), 63-68. doi:10.1080/ 15569543.2016.1217542

Bakkali, F., Averbeck, S., Averbeck, D., and Idaomar, M. (2008). Biological effects of essential oils--a review. Food Chem. Toxicol. 46 (2), 446-475. doi:10.1016/j. fct.2007.09.106

Barupal, T., Meena, M., and Sharma, K. (2019). Inhibitory effects of leaf extract of Lawsonia inermis on Curvularia lunata and characterization of novel inhibitory compounds by GC-MS analysis. Biotechnol. Rep. 23, e00335. doi:10.1016/j.btre. 2019.e00335

Bashir, S., Alam, M., Adhikari, A., Shrestha, R. L. S., Yousuf, S., Ahmad, B., et al. (2014). New antileishmanial sesquiterpene coumarins from Ferula narthex Boiss. Phytochem. Lett. 9, 46-50. doi:10.1016/j.phytol.2014.04.009

Batra, S., Kumar, A., and Sharma, A. (2020). GABA and 5-HT receptor mediated anxiolytic effect of essential oil of Ferula sumbul Hook. roots. Nat. Prod. J. 10 (3), 262-271. doi:10.2174/2210315509666190211123646

Bayrami, G., Boskabady, M. H., Iranshahi, M., and Gholamnezhad, Z. (2013). Relaxant effects of asafoetida extract and its constituent umbelliprenin on Guinea-pig tracheal smooth muscle. Chin. J. Integr. Med. 1-6, 28 doi:10.1007/ s11655-013-1550-3

Ben Salem, S., Znati, M., Jabrane, A., Casanova, J., and Ben Jannet, H. (2016). Chemical composition, antimicrobial, anti-acetylcholinesterase and cytotoxic activities of the root essential oil from the Tunisian Ferula lutea (Poir.). Maire (Apiaceae). 19 (4), 897-906. doi:10.1080/0972060X.2015.1137238

Benchabane, O., Hazzit, M., Baaliouamer, A., and Mouhouche, F. (2012). Analysis and antioxidant activity of the essential oils of Ferula vesceritensis Coss.et Dur. and Thymus munbyanus Desf. J. Essent. Oil-Bear. Plants. 15 (5), 774-781. doi:10.1080/0972060X.2012.10644119

Benchabane, O. T. (2014). Chemical composition and insecticidal activities of essential oils of two Algerian endemic plants: Ferula vesceritensis Coss. et Dur. 
and Thymus pallescens de Noe. Int. J. Agric. Sci. Res. 4 (6), 185-191. doi:10.1080/ 10942912.2017.1381112

Chandran, H., Meena, M., and Sharma, K. (2020a). Microbial biodiversity and bioremediation assessment through omics approaches. Front. Environ. Chem. 1, 570326. doi:10.3389/fenvc.2020.570326

Chandran, H., Meena, M., Barupal, T., and Sharma, K. (2020b). Plant tissue culture as a perpetual source for production of industrially important bioactive compounds. Biotechnol. Rep. (Amst). 26, e00450. doi:10.1016/j. btre.2020.e00450

Dadașoğlu, E., Öztekin, A., and Dadașoğlu, F. (2018). Antibacterial and antioxidant activity of essential oil and extracts of Ferula communis and determination of chemical composition of its essential oil. Fresenius Environ. Bull. 27 (6), 4186-4191. doi:10.1080/14786419.2015.1071365

Daneshkazemi, A., Zandi, H., Davari, A., Vakili, M., Emtiazi, M., Lotfi, R., et al. (2019). Antimicrobial activity of the essential oil obtained from the seed and oleo-gum-resin of Ferula assa-foetida against oral pathogens. Front. Dent. 16 (2), 113. doi:10.18502/fid.v16i2.1362

Dastan, D., Salehi, P., Ghanati, F., Gohari, A. R., Maroofi, H., and Alnajar, N. (2014). Phytotoxicity and cytotoxicity of disesquiterpene and sesquiterpene coumarins from Ferula pseudalliacea. Ind. Crop. Prod. 55, 43-48. doi:10.1016/j. indcrop.2014.01.051

Deniz, G. Y., Laloglu, E., Koc, K., and Geyikoglu, F. (2019). Hepatoprotective potential of Ferula communis extract for carbon tetrachloride induced hepatotoxicity and oxidative damage in rats. Biotech. Histochem. 94 (5), 334-340. doi:10.1080/10520295.2019.1566831

Deveci, E., Tel-Çayan, G., and Duru, M. E. (2018). Phenolic profile, antioxidant, anticholinesterase, and anti-tyrosinase activities of the various extracts of Ferula elaeochytris and Sideritis stricta. Int. J. Food Prop. 21 (1), 771-783. doi:10.1080/ 10942912.2018.1431660

Divya, K., Ramalakshmi, K., Murthy, P. S., and Rao, L. J. M. (2014). Volatile oils from Ferula asafoetida varieties and their antimicrobial activity. LWT Food Sci. Technol. (Lebensmittel-Wissenschaft -Technol.). 59 (2), 774-779. doi:10.1016/j. lwt.2014.07.013

El-Deeb, H. K., Al Khadrawy, F. M., and Abd El-Hameid, A. K. (2012). Inhibitory effect of Ferula asafoetida L. (Umbelliferae) on Blastocystis sp. subtype 3 growth in vitro. Parasitol. Res. 111 (3), 1213-1221. doi:10.1007/s00436-012-2955-1

Elghwaji, W., El-Sayed, A. M., El-Deeb, K. S., and ElSayed, A. M. (2017). Chemical composition, antimicrobial and antitumor potentiality of essential oil of Ferula tingitana L. Apiaceae grow in Libya. Phcog. Mag. 13 (3), 446-451. doi:10.4103/ pm.pm_323_15

Esmaeili, H., Esmailidehaj, M., Entezari Zarch, S., and Azizian, H. (2020). Role of the potassium channels in vasorelaxant effect of asafoetida essential oil. Avicenna J. Phytomed. 10 (4), 407-416. doi:10.1016/j.jep.2004.01.002

Esmaeili, H., Hafezimoghadam, Z., Esmailidehaj, M., Rezvani, M. E., and Hafizibarjin, Z. (2018). The effect of asafoetida essential oil on myocardial ischemic-reperfusion injury in isolated rat hearts. Avicenna J. Phytomed. 8 (4), 338-349. doi:10.22038/AJP.2018.10315

Esmaeili, H., Sharifi, M., Esmailidehaj, M., Rezvani, M. E., and Hafizibarjin, Z. (2017). Vasodilatory effect of Asafoetida essential oil on rat aorta rings: the role of nitric oxide, prostacyclin, and calcium channels. Phytomedicine. 36, 88-94. doi:10.1016/j.phymed.2017.10.002

Essid, R., Rahali, F. Z., Msaada, K., Sghair, I., Hammami, M., Bouratbine, A., et al. (2015). Antileishmanial and cytotoxic potential of essential oils from medicinal plants in Northern Tunisia. Ind. Crop. Prod. 77, 795-802. doi:10.1016/j.indcrop. 2015.09.049

Estekhdami, P., Dehsorkhi, A. N., and Kalvandi, R. (2020). Insecticidal efficacy of essential oils from Cinnamomum zeylanicum, Thymus vulgaris, Ferula assafoetida L on Callosobruchus maculatus F. Asian J. Agric. Res. 13 (2), 52-62. doi:10.9734/ajaar/2020/v13i230103

Fallah, F., Emadi, F., Ayatollahi, A., Taheri, S., Yazdi, M. K., and Rad, P. K. (2015). The anti-mycobacterial activity of the extract of Ferula gummosa. Int. J. Mycobacteriol. 4 (1), 166. doi:10.1016/j.ijmyco.2014.11.054

Fatemikia, S., Abbasipour, H., and Saeedizadeh, A. (2017). Phytochemical and acaricidal study of the galbanum, Ferula gummosa boiss. (Apiaceae) essential oil against Tetranychus urticae koch (tetranychidae). J. Essent. Oil-Bear. Plants. 20 (1), 185-195. doi:10.1080/0972060X.2016.1257957

Fatima, N., Fatmi, N., Shahzada, M., Sharma, S., Kumar, R., and Ali, M. (2017). Hepatoprotective effect of Ferula assafoetida against arsenic induced toxicity in
Swiss albino mice. J. Drug Discov. Dev. Deliv. 4 (1), 1030. doi:10.7324/JAPS. 2019.91107

Ghanbari, M., Zahedi Khorasani, M., and Vakili, A. (2012). Acute and chronic effects of Ferula persica on blood pressure of hypertensive rats and its possible mechanism of action. J. Med. Plants. 3 (43), 62-68. doi:10.31925/farmacia.2020.3.9

Ghannadi, A., Fattahian, K., Shokoohinia, Y., Behbahani, M., and Shahnoush, A. (2014). Anti-viral evaluation of sesquiterpene coumarins from Ferula assafoetida against HSV-1. Iran. J. Pharm. Res. (IJPR). 13 (2), 523. doi:10.22037/ijpr. 2014.1497

Ghasemi, V., Yazdi, A. K., Tavallaie, F. Z., and Sendi, J. J. (2014). Effect of essential oils from Callistemon viminalis and Ferula gummosa on toxicity and on the hemocyte profile of Ephestia kuehniella (Lep.: Pyralidae). Arch. Phytopathol. Pflanzenschutz. 47 (3), 268-278. doi:10.1080/03235408.2013.808856

Gholamnezhad, Z., Ghorani, V., Saadat, S., Shakeri, F., and Boskabady, M. H. (2018). The effects of medicinal plants on muscarinic receptors in various types of smooth muscle. Phytother Res. 32 (12), 2340-2363. doi:10.1002/ptr.6179

Goldansaz, S. H., Talaei, L., Poorjavad, N., and Dehghani, Y. H. (2012). "Inhibition of carob moth damage using Ferula assafoetida essential oil in pomegranate orchards of Iran", in 2nd International symposium on the pomegranate, vol. $103,129-131$.

Han, H. Y., Li, G. Y., Wang, H. Y., Ma, Q. D., Gao, J. B., and Wang, J. H. (2010). Anticoagulant activity of radiatinol and scopoletin from Ferula dissecta (Ledeb.) Ledeb. in vitro. J. Nongken Med. 2, 5. doi:10.11889/j.1000-3436.2016.rrj.34.020203

Hassanabadi, M., Ebrahimi, M., Farajpour, M., and Dejahang, A. (2019). Variation in essential oil components among Iranian Ferula assa-foetida L. accessions. Ind. Crop. Prod. 140, 111598. doi:10.1016/j.indcrop.2019.111598

Heydari-Majd, M., Rezaeinia, H., Shadan, M. R., Ghorani, B., and Tucker, N. (2019). Enrichment of zein nanofibre assemblies for therapeutic delivery of Barije (Ferula gummosa Boiss) essential oil. J. Drug Deliv. Sci. Technol. 54, 101290. doi:10.1016/j.jddst.2019.101290

Hosseinpour, M. H., Askarianzadeh, A., Moharramipour, S., and Jalali Sendi, S. (2011). Insecticidal activity of essential oils isolated from Rue (Ruta graveolens L.) and Galbanum (Ferula gummosa Bioss.) on Callosobruchus maculatus (F). Integr. Prot. Stored Prod. 69, 271-275. doi:10.3390/molecules24224047

Hosseinzadeh, N., Shomali, T., Hosseinzadeh, S., Raouf Fard, F., Pourmontaseri, M., and Fazeli, M. (2020a). Green synthesis of gold nanoparticles by using Ferula persica Willd. gum essential oil: production, characterization and in vitro anti-cancer effects. J. Pharm. Pharmacol. 72 (8), 1013-1025. doi:10.1111/jphp. 13274

Hosseinzadeh, N., Shomali, T., Hosseinzadeh, S., Raouf Fard, F., Jalaei, J., and Fazeli, M. (2020b). Cytotoxic activity of Ferula persica gum essential oil on murine colon carcinoma (CT26) and Vero cell lines. J. Essent. Oil Res. 32 (2), 169-177. doi:10.1080/10412905.2020.1729880

Hussain, A. I., Anwar, F., Hussain Sherazi, S. T., and Przybylski, R. (2008). Chemical composition, antioxidant and antimicrobial activities of basil (Ocimum basilicum) essential oils depends on seasonal variations. Food Chem. 108 (3), 986-995. doi:10.1016/j.foodchem.2007.12.010

Iranshahi, M., Rezaee, R., Najaf Najafi, M., Haghbin, A., and Kasaian, J. (2018). Cytotoxic activity of the genus Ferula (Apiaceae) and its bioactive constituents. Avicenna J. Phytomed. 8 (4), 296-312. doi:10.22038/AJP.2018.26953.1963

Iranshahi, M., and Alizadeh, M. (2012). Antihyperglycemic effect of asafoetida (Ferula assafoetida oleo-gum-resin) in streptozotocin-induced diabetic rats. World Appl. Sci. J. 17 (2), 157-162. doi:10.1016/j.jtcme.2016.11.004

Iranshahi, M., Fata, A., Emami, B., Shahr, B. M. J., and FazlyBazzaz, B. S. (2008). In vitro antifungal activity of polysulfides-rich essential oil of Ferula latisecta fruits against human pathogenic dermatophytes. Nat. Prod. Commun. 3, 1543-1546. doi:10.1177/2F1934578X0800300929

Iranshahy, M., Farhadi, F., Paknejad, B., Zareian, P., Iranshahi, M., Karami, M., et al. (2019). Gummosin, a sesquiterpene coumarin from Ferula assa-foetida is preferentially cytotoxic to human breast and prostate cancer cell lines. Avicenna J. Phytomed. 9 (5), 446-453. doi:10.22038/AJP.2019.12598

Iranshahy, M., and Iranshahi, M. (2011). Traditional uses, phytochemistry and pharmacology of asafoetida (Ferula assa-foetida oleo-gum-resin)-a review. J. Ethnopharmacol. 134 (1), 1-10. doi:10.1016/j.jep.2010.11.067

Izadi, H., Sarnevesht, M., Sadeghi, R., Mahdian, K., and Jalai, M. A. (2012). Toxic effects of pyriproxyfen, neemarin, acetamiprid and Ferula assafoetida essential oil on the common pistachio psylla, Agonoscena pistaciae. Arch. Phytopathol. Pflanzenschutz. 45 (18), 2236-2242. doi:10.1080/03235408.2012.724973 
Jahani, S., Salehi, M., Shakiba, A., Moradipour, A., and Forouzandeh, F. (2015). Production and study of antioxidant and antibacterial activities of gelatin nanocapsules containing Ferula assa-foetida essential oil. J. Arak Uni. Med. Sci. 18 (5), 33-48. doi:10.18502/fid.v16i2.1362

Juglal, S., Govinden, R., and Odhav, B. (2002). Spice oils for the control of cooccurring mycotoxin-producing fungi. J. Food Protect. 65, 683-687. doi:10. 4315/0362-028x-65.4.683

Kahraman, C., Topcu, G., Bedir, E., Tatli, I. I., Ekizoglu, M., and Akdemir, Z. S. (2019). Phytochemical screening and evaluation of the antimicrobial and antioxidant activities of Ferula caspica. M. Bieb. extracts. Saudi. Pharm. J. 27 (4), 525-531. doi:10.1016/j.jsps.2019.01.016

Karakaya, S., Göger, G., Bostanlik, F. D., Demirci, B., Duman, H., and Kilic, C. S. (2019a). Comparison of the essential oils of Ferula orientalis L., Ferula gosandrasica Peşmen and Quézel, and Hippomarathrum microcarpum Petrov and their antimicrobial activity. Turk. J. Pharm. Sci. 16 (1), 69-75. doi:10.4274/tjps.77200

Karakaya, S., Koca, M., Sytar, O., and Duman, H. (2019b). Determination of natural phenolic compounds of Ferula longipedunculata Peşmen and assessment their antioxidant and anticholinesterase potentials. Nat. Prod. Res. 14 (5), 1-3. doi:10.1080/14786419.2019.1619728

Karimi, A., Krähmer, A., Herwig, N., Hadian, J., Schulz, H., and Meiners, T. (2020). Metabolomics approaches for analysing effects of geographic and environmental factors on the variation of root essential oils of Ferula assafoetida L. J. Agric. Food Chem. 37, 1-31. doi:10.1021/acs.jafc.0c03681

Karimian, V., Sepehry, A., Barani, H., Ebrahimi, S. N., and Mirjalili, M. H. (2020). Productivity, essential oil variability and antioxidant activity of Ferula assafoetida L. oleo-gum-resin during the plant exploitation period. J. Essent. Oil Res. 1-11, 28. doi:10.1080/10412905.2020.1794988

Karimlar, S., Naderi, A., Mohammadi, F., Moslehishad, M., Delrish, E., Aghajanpour, L., et al. (2019). Hypoglycemic and hypolipidemic effects of Myrtus communis, Trachyspermum copticum and Ferula gummosa essential oils on streptozotocin induced diabetic rats. Int. J. Food Sci. Nutr. 6 (1), 1-8. doi:10. 29252/nfsr.6.1.1

Kasaian, J., Asili, J., and Iranshahi, M. (2016). Sulphur-containing compounds in the essential oil of Ferula alliacea roots and their mass spectral fragmentation patterns. Pharm. Biol. 54 (10), 2264-2268. doi:10.3109/13880209.2016.1152279

Kavoosi, G., Purfard, A. M., and Aram, F. (2012). Radical scavenging properties of essential oils from Zataria multiflora and Ferula assafoetida. Asian Pac. J. Trop. Biomed. 2 (3), 28. doi:10.1016/S2221-1691(12)60415-8

Kavoosi, G., and Purfard, A. M. (2013). Scolicidal effectiveness of essential oil from Zataria multiflora and Ferula assafoetida: disparity between phenolic monoterpenes and disulphide compounds. Comp. Clin. Pathol. 22 (5), 999-1005. doi:10.1007/s00580-012-1518-2

Kavoosi, G., and Rowshan, V. (2013). Chemical composition, antioxidant and antimicrobial activities of essential oil obtained from Ferula assa-foetida oleogum-resin: effect of collection time. Food Chem. 138 (4), 2180-2187. doi:10. 1016/j.foodchem.2012.11.131

Kavoosi, G., Shakiba, A., Ghorbani, M., Dadfar, S. M. M., and Purfard, A. M. (2015). Antioxidant, antibacterial, water binding capacity and mechanical behavior of gelatin-ferula oil film as a wound dressing material. Galen Medical J. 4 (2), 103-114.

Kavoosi, G., Tafsiry, A., Ebdam, A. A., and Rowshan, V. (2013). Evaluation of antioxidant and antimicrobial activities of essential oils from Carum copticum seed and Ferula assafoetida latex. J. Food Sci. 78 (2), 46. doi:10.1111/1750-3841.12020

Khajeh, M., Yamini, Y., Bahramifar, N., Sefidkon, F., and Pirmoradei, M. R. (2005). Comparison of essential oils compositions of Ferula assa-foetida obtained by supercritical carbon dioxide extraction and hydrodistillation methods. Food Chem. 91 (4), 639-644. doi:10.1016/j.foodchem.2004.06.033

Khalifaev, P. D., Sharopov, F. S., Safomuddin, A., Numonov, S., Bakri, M., Habasi, M., et al. (2018). Chemical composition of the essential oil from the roots of Ferula kuhistanica growing wild in Tajikistan. Nat. Prod. Commun. 13 (2), 220-222. doi:10.1177/1934578X1801300226

Khambhala, P., Verma, S., Joshi, S., Seshadri, S., and Kothari, V. (2016). Inhibition of bacterial quorum-sensing by Ferula asafoetida essential oil. Adv. Genet. Eng. 5 (2), 2169-0111. doi:10.4172/2169-0111.1000i105

Khazdair, M. R., Boskabady, M. H., Kiyanmehr, M., Hashemzehi, M., and Iranshahi, M. (2015). The inhibitory effects of Ferula assa-foetida on muscarinic receptors of Guinea-Pig tracheal smooth muscle. Jundishapur J. Nat. Pharm. Prod. 10 (3), e20008 doi:10.17795/jjnpp-20008
Khoury, M., El Beyrouthy, M., Eparvier, V., Ouaini, N., and Stien, D. (2018). Chemical diversity and antimicrobial activity of the essential oils of four Apiaceae species growing wild in Lebanon. J. Essent. Oil Res. 25-31, 55. doi:10.1080/10412905.2017.1372314

Kiasalari, Z., Khalili, M., Roghani, M., Heidari, H., and Azizi, Y. (2013). Antiepileptic and antioxidant effect of hydroalcoholic extract of Ferula assa foetida gum on pentylentetrazole-induced kindling in male mice. Basic Clin. Neurosci. 4 (4), 299-306.

Kim, J. W., Huh, J. E., Kyung, S. H., and Kyung, K. H. (2004). Antimicrobial activity of alk(en)yl sulfides found in essential oils of garlic and onion. Food Sci. Biotechnol. 13 (2), 235-239.

Koorki, Z., Shahidi-Noghabi, S., Mahdian, K., and Pirmaoradi, M. (2018). Chemical composition and insecticidal properties of several plant essential oils on the melon aphid, Aphis gossypii Glover (Hemiptera: aphididae). J. Essent. Oil-Bear. Plants. 21 (2), 420-429. doi:10.1080/0972060X.2018.1435308

Kose, E. O., Akta, Ö., Deniz, I. G., and Sarikürkçü, C. (2010). Chemical composition antimicrobial and antioxidant activity of essential oil of endemic Ferula lycia Boiss. J. Med. Plants Res. 4 (17), 1698-1703. doi:10. 5897/JMPR09.439

Kouyakhi, E. T., Naghavi, M. R., and Alayhs, M. (2008). Study of the essential oil variation of Ferula gummosa samples from Iran. Chem. Nat. Compd. 44 (1), 124-126. doi:10.1007/s10600-008-0038-4

Kovač, J., Šimunović, K., Wu, Z., Klančnik, A., Bucar, F., Zhang, Q., et al. (2015). Antibiotic resistance modulation and modes of action of (-)- $\alpha$-pinene in Campylobacter jejuni. PloS One. 10, e0122871. doi:10.1371/journal.pone.0122871

Labed-Zouad, I., Labed, A., Laggoune, S., Zahia, S., Kabouche, A., and Kabouche, Z. (2015). Chemical compositions and antibacterial activity of four essential oils from Ferula vesceritensis Coss. and Dur. against clinical isolated and food-borne pathogens. Record Nat. Prod. 9 (4), 518-525. doi:10.1177/1934578X1801300226

Latifi, E., Mohammadpour, A. A., Fathi, B., and Nourani, H. (2019). Antidiabetic and antihyperlipidemic effects of ethanolic Ferula assa-foetida oleo-gum-resin extract in streptozotocin-induced diabetic wistar rats. Biomed. Pharmacother. 110, 197-202. doi:10.1016/j.biopha.2018.10.152

Liu, T., Wang, C. J., Xie, H. Q., and Mu, Q. (2013). Guaiol-a naturally occurring insecticidal sesquiterpene. Nat. Prod. Commun. 8 (10), 1353-1354. doi:10.1177/ $1934578 X 1300801001$

Liu, T., Wang, L., Zhang, L., Jiang, H., Zhang, Y., and Mao, L. (2020). Insecticidal, cytotoxic and anti-phytopathogenic fungal activities of chemical constituents from the aerial parts of Ferula sinkiangensis. Nat. Prod. Res. 34 (10), 1430-1436. doi:10.1080/14786419.2018.1509328

Mahaki, H., Tanzadehpanah, H., Abou-Zied, O. K., Moghadam, N. H., Bahmani, A., Salehzadeh, S., et al. (2019). Cytotoxicity and antioxidant activity of Kamolonol acetate from Ferula pseudalliacea, and studying its interactions with calf thymus DNA (ct-DNA) and human serum albumin (HSA) by spectroscopic and molecular docking techniques. Process Biochem. 79, 203-213. doi:10.1016/j.procbio.2018.12.004

Mahboubi, M., Kazempour, N., and Mahboubi, M. (2011). Antimicrobial activity of Rosemary, Fennel and Galbanum essential oils against clinical isolates of Staphylococcus aureus. Biharean Biol. 5 (1), 4-7.

Mahendra, P., and Bisht, S. (2012). Ferula asafoetida: traditional uses and pharmacological activity. Pharmacogn. Rev. 6 (12), 141. doi:10.4103/09737847.99948

Malekzadeh, M., Angourani, H. R., Yazdinezhad, A., Hassan, M., Abiodun, F., and Hazrati, S. (2018). Evaluation of volatile oil in indigenous populations of Ferula gummosa boiss. J. Essent. Oil-Bear. Plants. 21 (1), 206-213. doi:10.1080/ 0972060X.2016.1244495

Mallahi, T., Ramezanian, A., Saharkhiz, M. J., Javanmardi, J., and Iraji, A. (2018). Antimicrobial activities of asafoetida and shirazi thyme essential oils improve the vase life of gerbera cut flowers. Acta Ecol. Sin. 38 (3), 228-233. doi:10.1016/j. chnaes.2017.08.009

Meena, M., Aamir, M., Vikas, K., Swapnil, P., and Upadhyay, R. S. (2018). Evaluation of morpho-physiological growth parameters of tomato in response to $\mathrm{Cd}$ induced toxicity and characterization of metal sensitive NRAMP3 transporter protein. Environ. Exp. Bot. 148, 144-167. doi:10.1016/ j.envexpbot.2018.01.007

Meena, M., and Samal, S. (2019). Alternaria host-specific (HSTs) toxins: an overview of chemical characterization, target sites, regulation and their toxic effects. Toxicol. Rep. 6, 745-758. doi:10.1016/j.toxrep.2019.06.021 
Meena, M., Sonigra, P., and Yadav, G. (2020a). Biological-based methods for the removal of volatile organic compounds (VOCs) and heavy metals. Environ. Sci. Pollut. Res. 11, 124. doi:10.1007/s11356-020-11112-4

Meena, M., Swapnil, P., Divyanshu, K., Kumar, S., Harish, Y. N., et al. (2020b). PGPR-mediated induction of systemic resistance and physiochemical alterations in plants against the pathogens: current perspectives. J. Basic Microbiol. 60 (8), 1-34. doi:10.1002/jobm.202000370

Meena, M., and Swapnil, P. (2019). Regulation of WRKY genes in plant defense with beneficial fungus Trichoderma: current perspectives and future prospects. Arch. Phytopathol. Plant Protect. 52 (1-2), 1-17. doi:10.1080/03235408.2019.1606490

Meena, M., Swapnil, P., Zehra, A., Dubey, M. K., and Upadhyay, R. S. (2017a). Antagonistic assessment of Trichoderma spp. by producing volatile and nonvolatile compounds against different fungal pathogens. Arch. Phytopathol. Plant Protect. 50 (13-14), 629-648. doi:10.1080/03235408.2017.1357360

Meena, M., Gupta, S. K., Swapnil, P., Zehra, A., Dubey, M. K., and Upadhyay, R. S. (2017b). Alternaria toxins: potential virulence factors and genes related to pathogenesis. Front. Microbiol. 8, 1451. doi:10.3389/fmicb.2017.01451

Meena, M., Swapnil, P., and Upadhyay, R. S. (2017c). Isolation, characterization and toxicological potential of tenuazonic acid, alternariol and alternariol monomethyl ether produced by Alternaria species phytopathogenic on plants. Sci. Rep. 7, 8777. doi:10.1038/s41598-017-09138-9

Meena, M., Zehra, A., Dubey, M. K., Aamir, M., Gupta, V. K., and Upadhyay, R. S. (2016). Comparative evaluation of biochemical changes in tomato (Lycopersicon esculentum Mill.) infected by Alternaria alternata and its toxic metabolites (TeA, AOH, and AME). Front. Plant Sci. 7, 1408. doi:10.3389/fpls.2016.01408

Moghaddam, M., and Farhadi, N. (2015). Influence of environmental and genetic factors on resin yield, essential oil content and chemical composition of Ferula assa-foetida L. populations. J. Appl. Res. Med. Aromat. Plants. 2 (3), 69-76. doi:10.1016/j.jarmap.2015.04.001

Mohammadhosseini, M. (2016). A Comprehensive Review on new methods for processing, separation and identification of the essential oils. Shahrood, Iran: Islamic Azad University of Shahrood Press, 61-73. doi:10.1016/j.indcrop.2017. 05.009

Mohammadhosseini, M., Akbarzadeh, A., and Flamini, G. (2017). Profiling of compositions of essential oils and volatiles of Salvia limbata using traditional and advanced techniques and evaluation for biological activities of their extracts. Chem. Biodivers. 14 (5), e1600361. doi:10.1002/cbdv.201600361

Mohammadhosseini, M. (2017). Essential oils extracted using microwave-assisted hydrodistillation from aerial parts of eleven Artemisia species: chemical compositions and diversities in different geographical regions of Iran. Record Nat. Prod. 11 (2), 114-129. https://www.acgpubs.org/doc/ 2018080513061416-RNP-EO_1602-010.pdf.

Mohammadhosseini, M., Mahdavi, B., and Shahnama, M. (2015). Chemical composition of essential oils from aerial parts of Ferula gummosa (Apiaceae) in Jajarm Region, Iran using traditional hydrodistillation and solvent-free microwave extraction methods: a comparative approach. J. Essent. Oil. Bear. Plants. 18 (6), 1321-1328. doi:10.1080/0972060X.2015.1024445

Mohammadhosseini, M., and Nekoei, M. (2014). Chemical compositions of the essential oils and volatile compounds from the aerial parts of Ferula ovina using hydrodistillation, MAHD, SFME and HS-SPME methods. J. Essent. Oil Bear. Plants. 17 (5), 747-757. doi:10.1080/0972060X.2014.884951

Mohammadhosseini, M., Venditti, A., and Akbarzadeh, A. (2019a). The genus Perovskia Kar.: ethnobotany, chemotaxonomy and phytochemistry: a review. Toxin Rev. 28, 1-22. doi:10.1080/15569543.2019.1691013

Mohammadhosseini, M., Venditti, A., Sarker, S. D., Nahar, L., and Akbarzadeh, A. (2019b). The genus Ferula: ethnobotany, phytochemistry and bioactivities-A review. Ind. Crop. Prod. 129, 350-394. doi:10.1016/j.indcrop.2018.12.012

Mohammadi, S., Ebrahimzadeh, H., Niknam, V., and Zahed, Z. (2019). Agedependent responses in cellular mechanisms and essential oil production in sweet Ferula assafoetida under prolonged drought stress. J. Plant Interact. 14 (1), 324-333. doi:10.1080/17429145.2019.1632946

Muturi, E. J., Ramirez, J. L., Zilkowski, B., Flor-Weiler, L. B., and Rooney, A. P. (2018). Ovicidal and larvicidal effects of garlic and asafoetida essential oils against West Nile virus vectors. J. Insect Sci. 18 (2), 1-6. doi:10.1093/jisesa/iey036

Nabavi, S. M., Ebrahimzadeh, M. A., Nabavi, S. F., Eslami, B., and Dehpour, A. A. (2011). Antioxidant and antihaemolytic activities of Ferula foetida regel (Umbelliferae). Eur. Rev. Med. Pharmacol. Sci. 15 (2), 157-164. https:// www.europeanreview.org/article/887.
Nazemisalman, B., Vahabi, S., Yazdinejad, A., Haghghi, F., Jam, M. S., and Heydari, F. (2018). Comparison of antimicrobial effect of Ziziphora tenuior, Dracocephalum moldavica, Ferula gummosa, and Prangos ferulacea essential oil with chlorhexidine on Enterococcus faecalis: an in vitro study. J. Dent. Res. 15 (2), 111-116. doi:10.4103/1735-3327.226525

Nguir, A., Mabrouk, H., Douki, W., Ismail, M. B., Jannet, H. B., and Flamini, G. (2016). Chemical composition and bioactivities of the essential oil from different organs of Ferula communis L. growing in Tunisia. Med. Chem. Res. 25 (3), 515-525. doi:10.1007/s00044-016-1506-1

Oüzek, G., Schepetkin, I. A., Utegenova, G. A., Kirpotina, L. N., andrei, S. R., Oüzek, T., et al. (2017). Chemical composition and phagocyte immunomodulatory activity of Ferula iliensis essential oils. J. Leukoc. Biol. 101 (6), 1361-1371. doi:10.1189/jlb.3A1216-518RR

Ozkan, H., Yanmis, D., Karadayi, M., Bal, T., Baris, O., and Gulluce, M. (2014). Determination of genotoxic and antigenotoxic properties of essential oil from Ferula orientalis L. using Ames/Salmonella and E. coli WP2 bacterial test systems. Toxicol. Ind. Health. 30 (8), 714-723. doi:10.1177/ 0748233712462479

Pavela, R., Morshedloo, M. R., Lupidi, G., Carolla, G., Barboni, L., Quassinti, L., et al. (2020). The volatile oils from the oleo-gum-resins of Ferula assa-foetida and Ferula gummosa: a comprehensive investigation of their insecticidal activity and eco-toxicological effects. Food Chem. Toxicol. 140, 111312. doi:10.1016/j.ft.2020.111312

Pavlović, I., Petrović, S., Radenković, M., Milenković, M., Couladis, M., Branković, S., et al. (2012). Composition, antimicrobial, antiradical and spasmolytic activity of Ferula heuffelii Griseb. ex Heuffel (Apiaceae) essential oil. Food Chem. 130 (2), 310-315. doi:10.1016/j.foodchem.2011.07.043

Poorjavad, N., Goldansaz, S. H., and Dadpour, H. (2014). Effect of Ferula assafoetida essential oil on some biological and behavioral traits of Trichogramma embryophagum and T. evanescens. Biocontrol. 59 (4), 403-413. doi:10.1007/s10526-014-9583-x

Prakash, B., Kedia, A., Mishra, P. K., and Dubey, N. K. (2015). Plant essential oils as food preservatives to control moulds, mycotoxin contamination and oxidative deterioration of agri-food commodities-potentials and challenges. Food Contr. 47, 381-391. doi:10.1016/j.foodcont.2014.07.023

Radulović, N. S., Zlatković, D. B., Randjelović, P. J., Stojanović, N. M., Novaković, S. B., and Akhlaghi, H. (2013). Chemistry of spices: bornyl 4-methoxybenzoate from Ferula ovina (Boiss.) Boiss.(Apiaceae) induces hyperalgesia in mice. Food Funct. 4 (12), 1751-1758. doi:10.1039/C3FO60319A

Ragab, T. I., El Gendy, A. N. G., Saleh, I. A., and Esawy, M. A. (2019). Chemical composition and evaluation of antimicrobial activity of the Origanum majorana essential oil extracted by microwave-assisted extraction, conventional hydro-distillation and steam distillation. J. Essent. Oil-Bear. Plants. 22 (2), 563-573. doi:10.1080/0972060X.2019.1611486

Rahali, F. Z., Kefi, S., Bettaieb Rebey, I., Hamdaoui, G., Tabart, J., Kevers, C., et al. (2019). Phytochemical composition and antioxidant activities of different aerial parts extracts of Ferula communis L. Plant Biosyst. 153 (2), 213-221. doi:10. 1080/11263504.2018.1461696

Rashidi, F., Khaksary, M. M., Ranjbar, R., and Najafzadeh, V. H. (2014). The Effects of essential oil of galbanum on caffeine induced-cleft palate in rat embryos. Zahedan. J. Res. Med. Sci. 16 (2), 37-41. doi:10.3329/bjp.v11i4.26915

Raut, J. S., and Karuppayil, S. M. (2014). A status review on the medicinal properties of essential oils. Ind. Crop. Prod. 62, 250-264. doi:10.1016/j. indcrop.2014.05.055

Rezaee, R., Behravan, E., Behravan, J., Soltani, F., Naderi, Y., Emami, B., et al. (2014). Antigenotoxic activities of the natural dietary coumarins umbelliferone, herniarin and 7-isopentenyloxy coumarin on human lymphocytes exposed to oxidative stress. Drug Chem. Toxicol. 37 (2), 144-148. doi:10.3109/01480545. 2013.834352

Rivas da Silva, A. C., Lopes, P. M., Barros de Azevedo, M. M., Costa, D. C., Alviano, C. S., and Alviano, D. S. (2012). Biological activities of alpha-pinene and betapinene enantiomers. Molecules. 17, 6305-6316.

Sadeghi, R., Hadizadeh Raeisi, N., and Jamshidnia, A. (2017). Immunological responses of Sesamia cretica to Ferula ovina essential oil. J. Insect Sci. 17 (1), 1-5. doi:10.1093/jisesa/iew124

Sadraei, H., Asghari, G. R., Hajhashemi, V., Kolagar, A., and Ebrahimi, M. (2001). Spasmolytic activity of essential oil and various extracts of Ferula gummosa Boiss. on ileum contractions. Phytomedicine. 8 (5), 370-376. doi:10.1078/0944-7113-00052 
Safaeian, L., Ghannadi, A., Javanmard, S. H., and Vahidian, M. H. (2015). The effect of hydroalcoholic extract of Ferula foetida stems on blood pressure and oxidative stress in dexamethasone-induced hypertensive rats. Res. Pharm. Sci. 10 (4), 326. doi:10.4103/1735-5362.220964

Sagyndykova, M. S., Imanbayeva, A. A., Suleimen, Y. M., and Ishmuratova, M. Y. (2019). Chemical composition and properties of essential oil of Ferula foetida (Bunge) Regel growing on Mangyshlak peninsula. 496, 27-34. doi:10.31489/ 2019Ch4/25-34

Salehi, M., Naghavi, M. R., and Bahmankar, M. (2019). A review of Ferula species: biochemical characteristics, pharmaceutical and industrial applications, and suggestions for biotechnologists. Ind. Crop. Prod. 139, 111511. doi:10.1016/j. indcrop.2019.111511

Satarian, F., Hosseini, H. M., Ghadaksaz, A., Amin, M., and Fooladi, A. A. (2018). Multi-drug resistant clinical Pseudomonas aeruginosas inhibited by Ferula gummosa Boiss. Recent Pat. Anti-Infect. Drug Discov. 13 (1), 89-99. doi:10. 2174/1574891X13666180426163427

Sayah, M., Kamalinezhad, M., Roustaeian, A., and Bahrami, H. R. (2001). Antiepileptic potential and composition of the fruit essential oil of Ferula gummosa boiss. Iran. Biomed. J. 5 (2-3), 69-72.

Schepetkin, I. A., Kushnarenko, S. V., Özek, G., Kirpotina, L. N., Sinharoy, P., Utegenova, G. A., et al. (2016). Modulation of human neutrophil responses by the essential oils from Ferula akitschkensis and their constituents. J. Agric. Food Chem. 64 (38), 7156-7170. doi:10.1021/acs.jafc.6b03205

Sepahi, E., Tarighi, S., Ahmadi, F. S., and Bagheri, A. (2015). Inhibition of quorum sensing in Pseudomonas aeruginosa by two herbal essential oils from Apiaceae family. J. Microbiol. 53 (2), 176-180. doi:10.1007/s12275-015-4203-8

Sharopov, F., Braun, M. S., Gulmurodov, I., Khalifaev, D., Isupov, S., and Wink, M. (2015). Antimicrobial, antioxidant, and anti-inflammatory activities of essential oils of selected aromatic plants from Tajikistan. Foods. 4 (4), 645-653. doi:10. 3390/foods 4040645

Sharopov, F. S., Khalifaev, P. D., Satyal, P., Sun, Y., Safomuddin, A., Musozoda, S., et al. (2019). The chemical composition and biological activity of the essential oil from the underground parts of Ferula tadshikorum (Apiaceae). Record Nat. Prod. 13 (1), 18-23. doi:10.25135/rnp.65.18.02.089

Sitara, U., Akbar, A., Abid, M., and Ahmad, A. (2018). Essential oils show antifungal activity against seed-borne mycoflora associated with okra seeds. Int. J. Biotechnol. Mol. Biol. Res. 15, 855-863. doi:10.3923/ajppaj.2012.66.74

Stepanycheva, E. A., Chakaeva, A. S., Savelieva, E. I., and Chermenskaya, T. D. (2012). Aphicidal activity of substances from roots of Ferula foetida (Bunge), Regel. against grain aphid, Schizaphis graminum (Rondani). Biopestic. Int. 8, $18-25$.

Tabari, M. A., Youssefi, M. R., Nasiri, M., Hamidi, M., Kiani, K., Samakkhah, S. A., et al. (2019). Towards green drugs against cestodes: effectiveness of Pelargonium roseum and Ferula gummosa essential oils and their main component on Echinococcus granulosus protoscoleces. Vet. Parasitol. 266, 84-87. doi:10.1016/j.vetpar.2018.12.019

Tavassoli, M., Jalilzadeh-Amin, G., Fard, V. R. B., and Esfandiarpour, R. (2018). The in vitro effect of Ferula asafoetida and Allium sativum extracts on Strongylus spp. Ann. Parasitol. 64 (1), 59-63. doi:10.17420/ap6401.133

Tempark, T., Chatproedprai, S., and Wananukul, S. (2016). Localized contact dermatitis from Ferula assa-foetida oleo-gum-resin essential oil, a traditional topical preparation for stomach ache and flatulence. Indian J. Dermatol. Venereol. Leprol. 82 (4), 467. doi:10.4103/0378-6323.182969

Teng, L., Ma, G. Z., Li, L., Ma, L. Y., and Xu, X. Q. (2013). Karatavicinol a, a new anti-ulcer sesquiterpene coumarin from Ferula sinkiangensis. Chem. Nat. Compd. 49 (4), 606-609. doi:10.1007/s10600-013-0690-1

Topdas, E. F., Sengul, M., Taghizadehghalehjoughi, A., and Hacimuftuoglu, A. (2020). Neuroprotective potential and antioxidant activity of various solvent extracts and essential oil of Ferula orientalis L. J. Essent. Oil-Bear. Plants. 23 (1), 121-138. doi:10.1080/0972060X.2020.1729247

Upadhyay, P. K. (2017). Pharmacological activities and therapeutic uses of resins obtained from Ferula asafoetida Linn.: a review. Int. J. Green Pharm. 11, 2. doi:10.22377/ijgp.v11i02.1033

Upadhyay, P. K., Singh, O., Yadav, A., and Sharma, R. (2014). A review on anxiolytic and antiepileptic effects of oleo-gum-resin of Ferula asafoetida. Am. J. Pharm. Heath Res. 2, 1-11. doi:10.4103/1947-2714.139296
Utegenova, G. A., Pallister, K. B., Kushnarenko, S. V., Özek, G., Özek, T., Abidkulova, K. T., et al. (2018). Chemical composition and antibacterial activity of essential oils from Ferula L. species against methicillin-resistant Staphylococcus aureus. Molecules. 23 (7), 1679. doi:10.3390/molecules23071679

Verma, S., Khambhala, P., Joshi, S., Kothari, V., Patel, T., and Seshadri, S. (2019). Evaluating the role of dithiolane rich fraction of Ferula asafoetida (apiaceae) for its antiproliferative and apoptotic properties: in vitro studies. Exp. Oncol. 4141 (22), 90-94. doi:10.32471/exp-oncology.2312-8852

Yaqoob, U., and Nawchoo, I. A. (2016). Distribution and taxonomy of Ferula L.: a review. Res. Rev. J. Biotechnol. 5 (3), 15-23. doi:10.3390/plants 9060740

Yarizade, A., Kumleh, H. H., and Niazi, A. L. I. (2017). In vitro antidiabetic effects of Ferula assa-foetida extracts through dipeptidyl peptidase IV and $\alpha$-glucosidase inhibitory activity. In Vitro. 10 (5), 357-360. doi:10.22159/ ajpcr.2017.v10i5.16648

Ye, B., Wang, S., and Zhang, L. (2011). Studies on the detoxification effects and acute toxicity of a mixture of cis-sec-butyl-1-propoenyl disulphide and transsec-butyl-1-propoenyl disulphide isolated from crude essential oil of Ferula sinkiangensis KM Shen, a Chinese traditional herbal medicine. Nat. Prod. Res. 25 (12), 1161-1170. doi:10.1080/14786419.2010.550027

Yusufoglu, H., Soliman, G., Abdel-Rahman, R., Abdel-Kader, M., Ganaie, M., Bedir, E., et al. (2015). Antihyperglycemic and antihyperlipidemic effects of Ferula duranii in experimental type 2 diabetic rats. Int. J. Pharmacol. 11 (6), 532-541. doi:10.3923/ijp.2015.532.541

Zahani, F. H., and Khaledi, N. (2018). Biological effects of various essential oils on citrus decay pathogens. Int. J. New Technol. Res. 4 (4), 129-139. doi:10.1155/ $2017 / 9268468$

Zandi-Sohani, N., Rajabpour, A., Yarahmadi, F., and Ramezani, L. (2018). Sensitivity of Bemisia tabaci (Hemiptera: aleyrodidae) and the generalist predator Orius albidipennis (Hemiptera: anthocoridae) to vapors of essential oils. J. Entomol. Sci. 53 (4), 493-502. doi:10.18474/JES17-113.1

Zellagui, A., Gherraf, N., and Rhouati, S. (2012). Chemical composition and antibacterial activity of the essential oils of Ferula vesceritensis Coss et Dur. leaves, endemic in Algeria. Bioorg. Med. Chem. Lett. 2 (1), 2191-2858. doi:10. 1186/2191-2858-2-31

Zhai, L. L., Liu, T., Xie, H. Q., Xie, Y. H., and Mu, Q. (2012). Inhibition effects on Hepatitis B virus replication by hydrophobic extracts from Ferula ferulaeoides (Steud.) Korov. J. Med. Plants Res. 6 (8), 1486-1488. doi:10. 5897/JMPR11.553

Zhou, Y., Xin, F., Zhang, G., Qu, H., Yang, D., and Han, X. (2017). Recent advances on bioactive constituents in Ferula. Drug Dev. Res. 78 (7), 321-331. doi:10.1002/ ddr. 21402

Znati, M., Filali, I., Jabrane, A., Casanova, J., Bouajila, J., and Ben Jannet, H. (2017). Chemical composition and in vitro evaluation of antimicrobial, antioxidant and antigerminative properties of the seed oil from the Tunisian endemic Ferula tunetana Pomel ex Batt. Chem. Biodivers. 14 (1), e1600116. doi:10.1002/cbdv. 201600116

Znati, M., Jabrane, A., Hajlaoui, H., Harzallah-Skhiri, F., Bouajila, J., Casanova, J., et al. (2012). Chemical composition and in vitro evaluation of antimicrobial and anti-acetylcholinesterase properties of the flower oil of Ferula lutea. Nat. Prod. Commun. 7 (7), 947-950. doi:10.1177/1934578X1200700738

Zomorodian, K., Saharkhiz, J., Pakshir, K., Immeripour, Z., and Sadatsharifi, A. (2018). The composition, antibiofilm and antimicrobial activities of essential oil of Ferula assa-foetida oleo-gum-resin. Biocatal. Agric. Biotechnol. 14, 300-304. doi:10.1016/j.bcab.2018.03.014

Conflict of Interest: The authors declare that the research was conducted in the absence of any commercial or financial relationships that could be construed as a potential conflict of interest.

Copyright (C) 2021 Sonigra and Meena. This is an open-access article distributed under the terms of the Creative Commons Attribution License (CC BY). The use, distribution or reproduction in other forums is permitted, provided the original author(s) and the copyright owner(s) are credited and that the original publication in this journal is cited, in accordance with accepted academic practice. No use, distribution or reproduction is permitted which does not comply with these terms. 